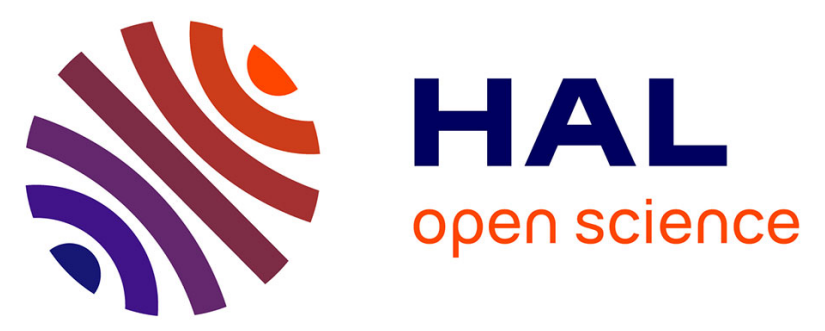

\title{
Wind-driven changes of surface current, temperature, and chlorophyll observed by satellites north of New Guinea
}

Marie-Hélène Radenac, Fabien Léger, Monique Messié, Pierre Dutrieux, Christophe E. Menkès, Gérard Eldin

\section{To cite this version:}

Marie-Hélène Radenac, Fabien Léger, Monique Messié, Pierre Dutrieux, Christophe E. Menkès, et al.. Wind-driven changes of surface current, temperature, and chlorophyll observed by satellites north of New Guinea. Journal of Geophysical Research. Oceans, 2016, 121 (4), pp.2231 - 2252. 10.1002/2015jc011438 . hal-01497605

\section{HAL Id: hal-01497605 https://hal.science/hal-01497605}

Submitted on 6 Jan 2022

HAL is a multi-disciplinary open access archive for the deposit and dissemination of scientific research documents, whether they are published or not. The documents may come from teaching and research institutions in France or abroad, or from public or private research centers.
L'archive ouverte pluridisciplinaire HAL, est destinée au dépôt et à la diffusion de documents scientifiques de niveau recherche, publiés ou non, émanant des établissements d'enseignement et de recherche français ou étrangers, des laboratoires publics ou privés. 


\section{Journal of Geophysical Research: Oceans}

\section{RESEARCH ARTICLE}

10.1002/2015JC011438

Key Points:

- SST and surface chlorophyll in relation to wind and surface currents in the Bismarck Sea

- A coastal upwelling develops during westerly wind events, austral summer, and El Niño

- Solomon Sea cold water spreads along the New Guinea coast during austral winter and El Niño

Correspondence to:

M.-H. Radenac,

marie-helene.radenac@legos.obs-mip.fr

Citation:

Radenac, M.-H., F. Léger, M. Messié, P. Dutrieux, C. Menkes, and G. Eldin (2016), Wind-driven changes of surface current, temperature, and chlorophyll observed by satellites north of New Guinea, J. Geophys. Res. Oceans, 121 2231-2252, doi:10.1002/

2015JC011438.

Received 4 NOV 2015 Accepted 9 MAR 2016 Accepted article online 14 MAR 2016 Published online 2 APR 2016

\section{Wind-driven changes of surface current, temperature, and chlorophyll observed by satellites north of New Guinea}

\author{
Marie-Hélène Radenac ${ }^{1}$, Fabien Léger ${ }^{1,2}$, Monique Messié ${ }^{3}$, Pierre Dutrieux $^{4}$, Christophe Menkes ${ }^{5}$, \\ and Gérard Eldin ${ }^{1}$
}

${ }^{1}$ LEGOS, Université de Toulouse, CNES, CNRS, IRD, UPS, Toulouse, France, ${ }^{2}$ Now at CNRM-GAME, UMR3589 CNRS/MétéoFrance, Toulouse, France, ${ }^{3}$ Monterey Bay Aquarium Research Institute, Monterey, California, USA, ${ }^{4}$ Polar Science Center, Applied Physics Laboratory, University of Washington, Seattle, Washington, USA, ${ }^{5}$ IRD/LOCEAN, Centre de Nouméa, Noumea, New Caledonia

\begin{abstract}
Satellite observations of wind, sea level and derived currents, sea surface temperature (SST), and chlorophyll are used to expand our understanding of the physical and biological variability of the ocean surface north of New Guinea. Based on scarce cruise and mooring data, previous studies differentiated a trade wind situation (austral winter) when the New Guinea Coastal Current (NGCC) flows northwestward and a northwest monsoon situation (austral summer) when a coastal upwelling develops and the NGCC reverses. This circulation pattern is confirmed by satellite observations, except in Vitiaz Strait where the surface northwestward flow persists. We find that intraseasonal and seasonal time scale variations explain most of the variance north of New Guinea. SST and chlorophyll variabilities are mainly driven by two processes: penetration of Solomon Sea waters and coastal upwelling. In the trade wind situation, the NGCC transports cold Solomon Sea waters through Vitiaz Strait in a narrow vein hugging the coast. Coastal upwelling is generated in westerly wind situations (westerly wind event, northwest monsoon). Highly productive coastal waters are advected toward the equator and, during some westerly wind events, toward the eastern part of the warm pool. During El Niño, coastal upwelling events and northward penetration of Solomon Sea waters combine to influence SST and chlorophyll anomalies.
\end{abstract}

\section{Introduction}

Small changes in sea surface temperature (SST) of the western Pacific warm pool may influence the onset of El Niño events and strongly impact the world climate [Godfrey and Lindstrom, 1989; Webster and Lukas, 1992]. In addition, important fishing fleets operate in the warm pool, and about $25 \%$ of the world tuna are caught in the Exclusive Economic Zones of the Pacific Island Countries and Territories [Bell et al., 2011]. In the way of the Southern Hemisphere Low Latitude Western Boundary Currents, the region north of New Guinea with its rivers and complicated bathymetry (Figure 1) influences physical and biological properties of the warm pool, the equatorial system, and the Indonesian Throughflow.

In this context, several studies focused on the western boundary currents along the New Guinea coast [Lindstrom et al., 1987; Cresswell, 2000; Ueki et al., 2003] since Wyrtki's [1957, 1961] pioneering work. The ocean-atmosphere interactions in the western Pacific warm pool have been largely studied [Webster and Lukas, 1992, among others]. The thermohaline structure and heat budget north of New Guinea, however, received little attention. Early description of a coastal upwelling appeared in Colin et al. [1973]. More recently, Hasegawa et al. [2009, 2010] mentioned the possible influence of the New Guinea upwelling on the warm pool heat budget. Biological and/or chemical observations are even scarcer [Colin et al., 1973; Mackey et al., 2002; Muchtar, 2004; Higgins et al., 2006; Burns et al., 2008]. In the following, we synthesize the literature results that give a somewhat partial view of the region, mostly based on the contrast between the two dominant wind regimes. To illustrate the literature review, we present average and standard deviation maps (Figure 2) of the data fields (see section 2) that will be further analyzed in this study.

Atmospheric Variability. Winds north of New Guinea are strongly influenced by seasonal monsoons. The average zonal wind stress is close to zero, slightly positive in the Bismarck Sea and along the New Guinea and Indonesian coasts, and negative in the Solomon Sea (Figure 2a). The variability increases along the
(C) 2016. American Geophysical Union. All Rights Reserved. 


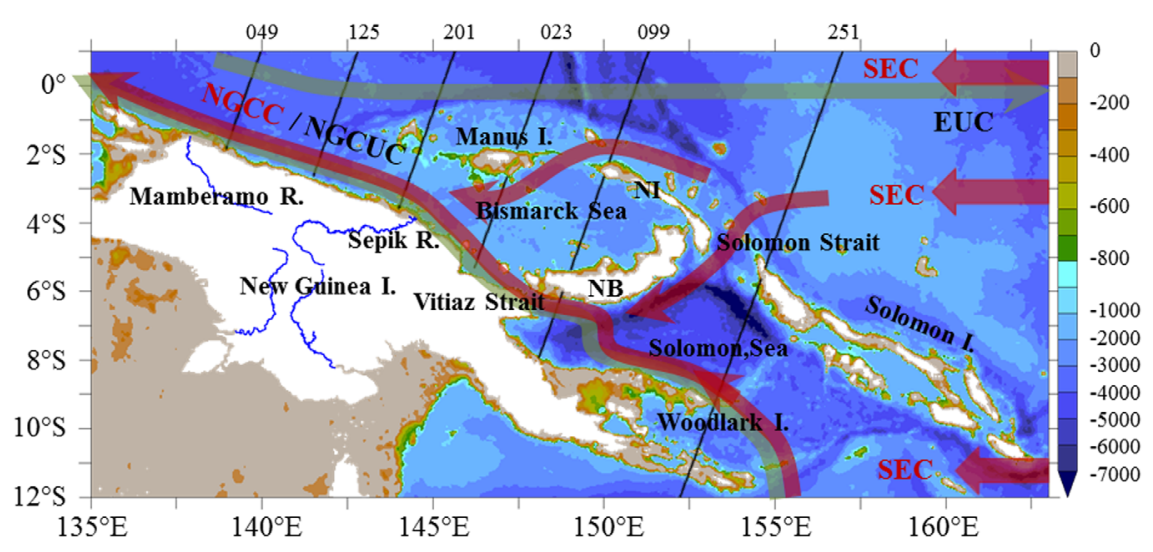

Figure 1. Bathymetry $(\mathrm{m})$ and main geographical features in the New Guinea region. NB and NI stand for New Britain and New Ireland Islands, respectively. Ascending altimetric tracks used in this study are overlaid. Numbers indicate tracks used in this study. The main surface (red arrows) and subsurface (grey arrows) currents north of New Guinea (adapted from Fieux [2010], Cravatte et al. [2011], and Hristova and Kessler [2012]) are superimposed: New Guinea Coastal Current (NGCC), New Guinea Coastal Undercurrent (NGCUC), Equatorial Undercurrent (EUC), and South Equatorial Current (SEC).

northern coast of New Guinea (Figure 2b) where the seasonal component of the wind is strong. The high mountains constrain the wind flow along the coast. Trade winds blow from the south-east along the New Guinea coast during austral winter. Winds reverse in summer during the northwest monsoon period. Intraseasonal activity in the western equatorial Pacific is characterized by westerly wind events (WWE). They are more numerous between September and January and during the growing phase of El Niño [Harrison and Vecchi, 1997; Eisenman et al., 2005; Puy et al., 2015]. Rainfall is strong when the wind is westerly and minimum during the trade wind season [Smith et al., 2012]. Drier conditions are often observed during the mature phase of El Niño and wetter conditions during mature La Niña [Ropelewski and Halpert, 1996; Smith et al., 2013]. However, the distribution of rainfall varies regionally because of the mountainous character of the islands and disparities are found among different rain products [Smith et al., 2013]. Because of the monsoonal aspect of precipitation, the Sepik River runoff is maximum in March-April and minimum in AugustSeptember [Kineke et al., 2000; Delcroix et al., 2014]. Its discharge diminishes during El Niño events [Kineke et al., 2000; Higgins et al., 2006].

Ocean Circulation. The intricate bathymetry constrains the Southern Hemisphere low-latitude western boundary currents to convoluted pathways around numerous islands and through narrow straits on their way to the equator (Figure 1). The Vitiaz Strait, connecting Solomon Sea and Bismarck Sea near the New Guinea mainland, is about $50 \mathrm{~km}$ wide and $1100 \mathrm{~m}$ deep [Lindstrom et al., 1990]. The boundary current system comprises the New Guinea Coastal Current (NGCC) in the surface layer and the New Guinea Coastal Undercurrent (NGCUC) in the thermocline layer, the variability of which are closely related to wind stress forcing at intraseasonal to interannual time scales [Kuroda, 2000; Ueki et al., 2003]. While the NGCUC always flows northwestward, the NGCC flows northwestward in austral winter and reverses to southeastward in summer in relation to the monsoon [Wyrtki, 1961; Colin et al., 1973; Murray et al., 1995; Kuroda, 2000; Ueki et al., 2003]. At the interannual time scale, equatorward transport increases in Vitiaz Strait during El Niño growing phase [Ueki et al., 2003]. Interestingly, the seasonal NGCC reversal was not observed in the Bismarck Sea during the 1997-1998 El Niño event [Ueki et al., 2003]. The surface signature of the NGCC is poorly represented in gridded satellite-derived velocity products [Hristova and Kessler, 2012, Figure 2] and description of its seasonal and interannual variations mainly relies on irregular cruises and limited time series of the two Japan Agency for Marine-Earth Science and Technology (JAMSTEC) moorings offshore at $142^{\circ} \mathrm{E}$. Besides, waters west of $142^{\circ} \mathrm{E}$ are largely undersampled leaving regional dynamics poorly constrained by observations.

Sea Surface Temperature. On average, the SST is higher than $29^{\circ} \mathrm{C}$ in the northern part of the region and decreases slightly near the coast (Figure 2c). Its variability is low in the Bismarck Sea while it is higher in the Solomon Sea (Figure 2d). Observations along transects off the New Guinea coast during the northwest monsoon showed cool and salty waters near the coast as a consequence of the wind-driven upwelling [Lukas, 1988; Kuroda, 2000; Ueki et al., 2003; Delcroix et al., 2014]. Such relatively low SST impacts the heat budget 


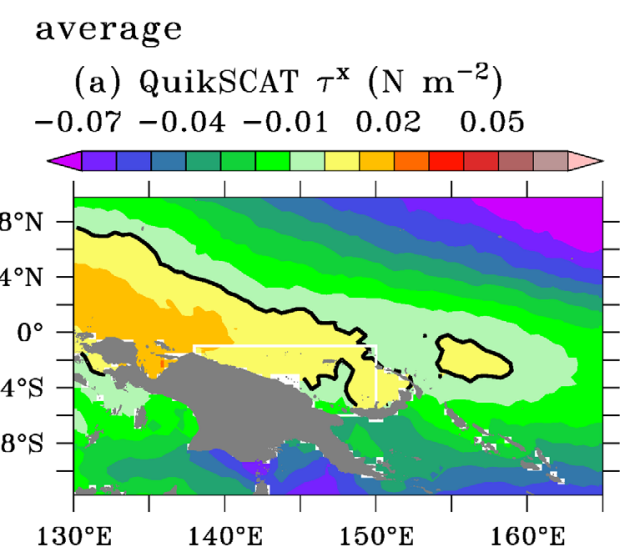

(c) AVHRR SST $\left({ }^{\circ} \mathrm{C}\right)$

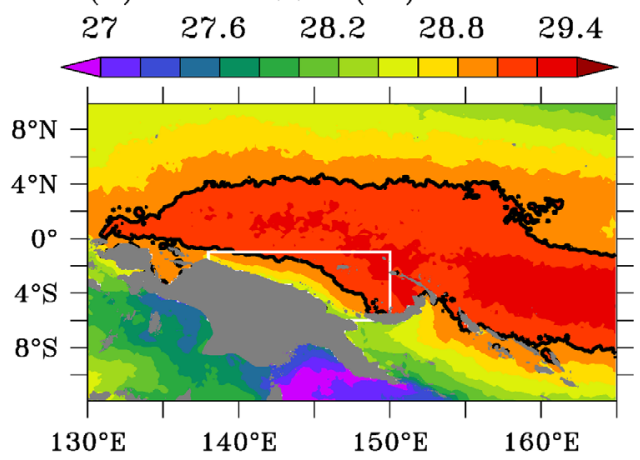

(e) SeaWiFS chl $\left(\mathrm{mg} \mathrm{m}^{-3}\right)$

$\begin{array}{llllll}0 & 0.12 & 0.16 & 0.2 & 0.24 & 0.28\end{array}$

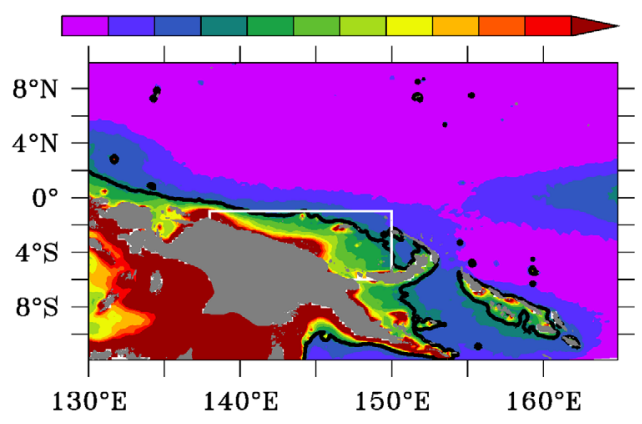

standard deviation

(b) QuikSCAT $\tau^{\mathrm{x}}\left(\mathrm{N} \mathrm{m}^{-2}\right)$

$\begin{array}{llllll}0.03 & 0.04 & 0.05 & 0.06 & 0.07 & 0.08\end{array}$

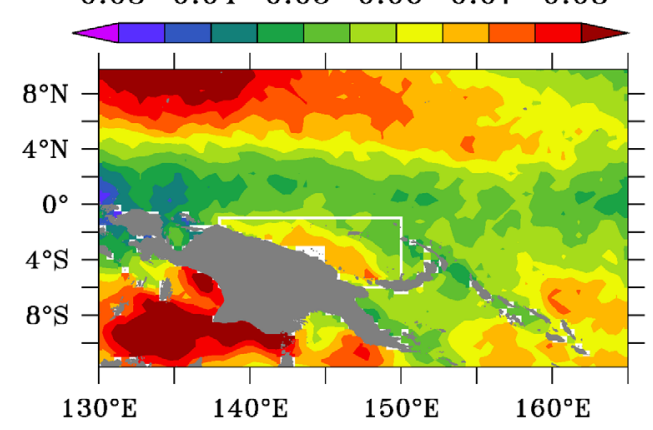

(d) AVHRR SST $\left({ }^{\circ} \mathrm{C}\right)$

$\begin{array}{llllll}0.3 & 0.5 & 0.7 & 0.9 & 1.1 & 1.3\end{array}$

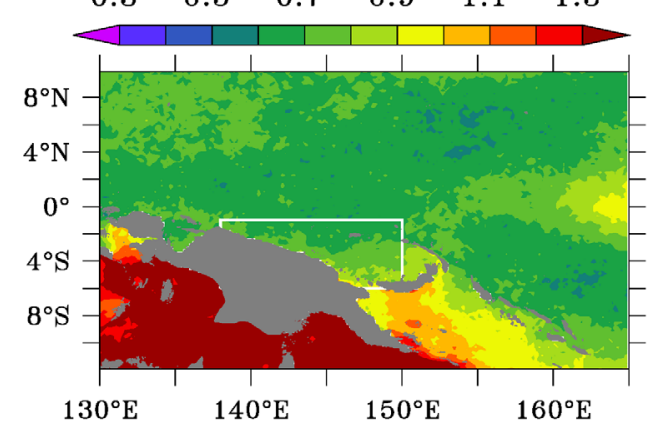

(f) SeaWiFS chl $\left(\mathrm{mg} \mathrm{m}^{-3}\right)$

$\begin{array}{lllll}0 & 0.02 & 0.04 & 0.06 & 0.08\end{array}$

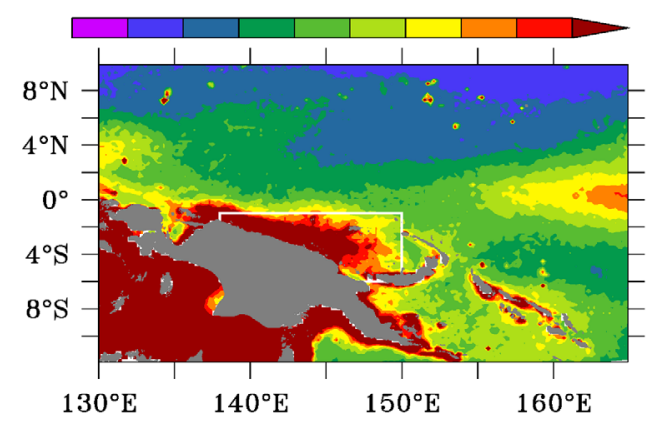

Figure 2. (left) Average and (right) standard deviation of (a, b) zonal wind stress, (c, d) SST, and (e, f) surface chlorophyll. Black contours mark the $0 \mathrm{~N} \mathrm{~m}^{-2}$ zonal wind stress isoline, $29^{\circ} \mathrm{C}$ isotherm, and $0.15 \mathrm{mg} \mathrm{m}^{-3}$ chlorophyll isoline. Calculations have been made during the SeaWiFS period (September 1997 to December 2010).

of the upper layer of the warm pool and may influence the onset of El Niño events [Hasegawa et al., 2009, 2010]. Recently, Delcroix et al. [2014] showed that seasonal advection of cooler waters from the Solomon Sea is another source of cooling in the region. How these two processes combine and how they vary at the intraseasonal, seasonal, and interannual time scales remains to be analyzed.

Biological Productivity. The mean surface chlorophyll and its variability are higher north of New Guinea than elsewhere in the warm pool where oligotrophic conditions prevail (Figure 2e). In the oligotrophic warm pool, thermal stratification separates a warm, nutrient-depleted isothermal surface layer from a cold, subsurface nutrient pool. A subsurface maximum in biological production appears at the top of the thermocline where the best compromise between light and nutrient limitations is found [Radenac and Rodier, 1996]. Closer to the coast, such features have been reported during the trade wind season [Everitt et al., 1990; Kaneko et al., 1998; Higgins et al., 2006], while higher biological production attributed to wind-induced upwelling is observed in January-February [Colin et al., 1973; Higgins et al., 2006]. Along the coast, the 
NGCUC carries waters with high macronutrient (nitrate, phosphate, and silicate) concentrations [Tsuchiya et al., 1989; Kaneko et al., 1998], also enriched in dissolved and particulate iron by sedimentary release along the continental slope of New Guinea [Lacan and Jeandel, 2001; Mackey et al., 2002; Slemons et al., 2010; Radic et al., 2011]. The wind-driven upwelling occurs when turbidity is strong because of rainfall and riverine inputs during the monsoon season in austral summer. Then, despite limited light penetration, the vertical supply of macronutrients and micronutrients is sufficient to cause biological production increases and a shift toward more mesotrophic conditions [Higgins et al., 2006]. The scarcity of biological observations has not allowed a clear description of the interannual variability. Patterns associated with wind and current changes at the intraseasonal, seasonal, and interannual time scales can be deduced from a satellite multisensor analysis. It also allows proposing processes responsible for these surface signatures.

Building on the precious but partial views offered by in situ observations, multivariate satellite observations (section 2) offer a prism through which links between regional oceanography and biological productivity can be further investigated. In the following, we examine the intraseasonal to interannual variability of wind and its relationship with patterns of surface circulation, SST, and surface chlorophyll from Vitiaz Strait to the northern tip of New Guinea. The main regional modes of variability that explain variances shown in Figure 2 are examined (section 3). Then, we analyze processes that led to spatial patterns identified at the intraseasonal (section 4), seasonal (section 5), and interannual (section 6) time scales. Concluding remarks follow in the last section. Note that we use Southern Hemisphere seasons throughout the rest of the article.

\section{Data and Methods}

\subsection{Satellite SST and Chlorophyll}

Surface chlorophyll concentrations were primarily derived from Sea-viewing Wide Field-of-view Sensor (SeaWiFS) between September 1997 and December 2010. When a SeaWiFS monthly map was not available or had less than $60 \%$ of data available (seven maps, i.e., $4.4 \%$ of the time), we used the Aqua MODIS map in order to obtain a complete chlorophyll time series from September 1997 to December 2010 [Radenac et al., 2012]. We used 9 km, 8 day and monthly composites (SeaWiFS R2010.0 and MODIS R2013.0 reprocessing) computed by the Ocean Biology Processing Group at the NASA Goddard Space Flight Center (GSFC) [McClain et al., 2004]. Eight day composites are used for the intraseasonal variability analysis, and the monthly temporal resolution is sufficient for the seasonal and interannual variability analyses.

Two data sets of satellite SST were used. Infrared SST was derived from NOAA Advanced Very High Resolution Radiometer (AVHRR) Pathfinder Version 5.2 [Casey et al., 2010]. Only nighttime daily maps (4 km resolution) were used to avoid a diurnal warm bias. The AVHRR data set was averaged monthly between January 1995 and December 2010 to reduce data gaps due to clouds and is used for the seasonal and interannual variability analyses when monthly resolution is sufficient. Its relatively high spatial resolution allows detecting the fine scale features along the coast and in the straits. Microwave SST was derived from the Tropical Rainfall Measuring Mission Microwave Imager (TMI) starting in December 1997 . Weekly maps with a $0.25^{\circ} \times 0.25^{\circ}$ grid were downloaded from the Remote Sensing Systems (RSS) web site. In the tropical Pacific, TMI SST do not show a significant warm bias relative to AVHRR SST in open waters [O'Carroll et al., 2006]. However, land contamination induces a warm bias near the coasts [O'Carroll et al., 2006; Reynolds et al., 2010]. Despite an extended land mask, TMI SST is still $1.2^{\circ} \mathrm{C}$ warmer on average than infrared SST north of New Guinea $\left(138^{\circ} \mathrm{E}-150^{\circ} \mathrm{E}, 6^{\circ} \mathrm{S}-1^{\circ} \mathrm{S}\right.$; white box in Figure 2$)$ because of land contamination in TMl data and a possible negative bias in AVHRR data. Although its coastal coverage is relatively poor, TMI improves the overall coverage in case of high cloudiness. TMI SST is used for the intraseasonal variability analysis that requires higher temporal resolution (weekly) and hence is more susceptible to clouds.

Data gaps due to cloud cover remain in the AVHRR SST and chlorophyll monthly maps whereas wavelet and Fourier analyses used to document seasonal and interannual variability require no missing data. We applied a spatial smoothing adapted from Yoder and Kennelly [2003] to fill missing values in the SST and surface chlorophyll time series. First, at each location, values that were more than five standard deviations away from the mean value were treated as missing [Messié and Radenac, 2006]. Then, SST and chlorophyll maps were downgraded on the same $0.2^{\circ} \times 0.2^{\circ}$ grid using the maximum likelihood estimator defined by Campbell et al. [1995] which is close to a geometric mean. Finally, remaining gaps were filled using a $1^{\circ} \times$ $1^{\circ}$ box average smoother. This last step was iterated until no data gaps remained. 


\subsection{Wind and Surface Currents}

Wind stress data were retrieved from the ERS-2 satellite and QuikSCAT scatterometers. Both wind products are weekly maps delivered by the Centre ERS d'Archivage et de Traitement (CERSAT), IFREMER, on a $1^{\circ} \times 1^{\circ}$ grid until 15 January 2001 for ERS- 2 and on a $0.5^{\circ} \times 0.5^{\circ}$ grid between August 1999 and November 2009 for QuikSCAT [Bentamy et al., 2002]. Both of them were interpolated onto the same $0.5^{\circ} \times 0.5^{\circ} \mathrm{grid}$. ERS- 2 wind stress is less energetic than QuikSCAT wind stress and in order to avoid a discontinuity, the ERS-2 data were regressed onto the QuikSCAT data during the common period (August 1999 to January 2001). Then, the two time series were merged.

Five day near-surface currents were obtained from the Ocean Surface Current Analysis - Real time (OSCAR) $1^{\circ} \times 1^{\circ}$ product for which the geostrophic and wind-driven components were derived from satellite data [Bonjean and Lagerloef, 2002]. Maps of geostrophic current anomaly were produced on a $1 / 3^{\circ} \times 1 / 3^{\circ}$ grid by Ssalto/Duacs multimission processing system and distributed by Archiving, Validation and Interpretation of Satellite Oceanographic data (AVISO) [AVISO, 1996]. We also used the shipboard Acoustic Doppler Current Profiler (SADCP) data from the Japan Agency for Marine-Earth Science and Technology (JAMSTEC) cruises collected by Dutrieux [2009] and the Joint Archive for SADCP (JASADCP) data at the University of Hawaii. SADCP spatial and temporal distributions allow constructing mean meridional transects of alongshore velocity during the trade wind season (December-February; six cruises) and the northwest monsoon season (June-September; seven cruises). ADCP moorings in the New Guinea Coastal Current system along $142^{\circ} \mathrm{E}$ $\left(2^{\circ} \mathrm{S}\right.$ and $\left.2.5^{\circ} \mathrm{S}\right)$ were maintained by the Tropical Ocean Climate Study (TOCS) group of the JAMSTEC from 1995 to 2006 [Kuroda, 2000]. Websites used to download the different data are listed in the "Acknowledgments" section.

\subsection{Estimation of the Cross-Track Geostrophic Current Anomaly From Satellite Sea Level Anomaly}

Along-track sea level anomalies (SLA) were derived from multimission (TOPEX/Poseidon, Jason 1, and Jason 2) Geophysical Data Records (GDR) at a $1 \mathrm{~Hz}$ rate (about $6 \mathrm{~km}$ spacing) supplied by AVISO. The altimetric data set has been reprocessed with the XTRACK software [Birol et al., 2010; Roblou et al., 2011] at the Centre de Topographie des Océans et de l'Hydrosphère $(\mathrm{CTOH})$ in order to improve the different corrections (especially tides and local ocean response to wind and atmospheric pressure forcing) in coastal regions. Five tracks (from Vitiaz Strait to the northern tip of New Guinea: labeled 099, 023, 201, 125, and 049) are almost perpendicular to the northern coast of New Guinea (Figure 1) and therefore to the alongshore surface current. Track 251 is also used to calculate the current anomaly in the NGCC in the Solomon Sea as in Melet et al. [2010]. We used data sampled with a 10 day period since March 1993, linearly interpolated onto a regular spacing of $6.1 \mathrm{~km}$ along the tracks.

Before computing the cross-track current anomaly, we postprocessed the SLA data to remove incorrect data by applying a slope criterion on SLA [Durand et al., 2008]. Assuming that the boundary current is in geostrophic equilibrium, the SLA gradient is related to the geostrophic velocity anomaly $U_{f}$ through the geostrophic relation in the $f$-plane:

$$
U_{f}=\frac{g}{f} \frac{\partial \eta}{\partial l}
$$

where $f$ is the Coriolis parameter, $g$ is gravity, $\eta$ is the SLA, and $\partial l$ is the distance between altimetric points with the along-track axis orientated northward. Assuming an upper-bound for $U_{f}$ of $3 \mathrm{~m} \mathrm{~s}^{-1}$ in the NGCC (highest velocity are around $1.2 \mathrm{~m} \mathrm{~s}^{-1}$ in the SADCP database and $1.5 \mathrm{~m} \mathrm{~s}^{-1}$ at the $142^{\circ} \mathrm{E}$ ADCP moorings), the associated SLA difference cannot exceed $5 \mathrm{~cm}$ using a centered finite difference. Values above the $5 \mathrm{~cm}$ threshold are discarded.

Assuming the hydrostatic balance near the equator [Joyce et al., 1988], we computed a geostrophic current approximation $\left(U_{\beta}\right)$ using the $\beta$-plane geostrophic derivation calculated with a second-order finite difference scheme as in Lukas and Firing [1984] and Picaut et al. [1990]:

$$
U_{\beta}=\frac{g}{\beta} \frac{\partial^{2} \eta}{\partial l^{2}}
$$

where $\beta$ is $2.3 \times 10^{-11} \mathrm{~m}^{-1} \mathrm{~s}^{-1}$. 


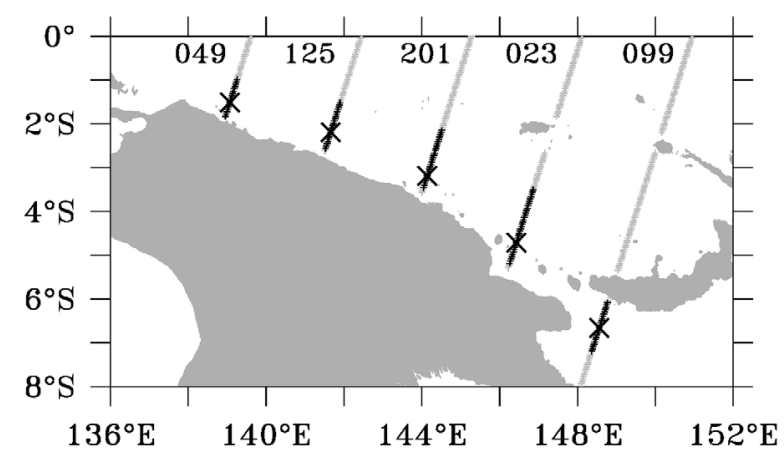

Figure 3. Location of the NGCC deduced from altimetric current anomalies. Crosses are locations of maximum variability of current anomaly $\left(\sigma_{\text {max }}\right)$. The along-track region in which standard deviation is higher than $\sigma_{\max } / 2$ is darkened. Track numbers are indicated.
Deriving SLA gradients tends to increase noise, so the along-track SLA was filtered using Gaussian windows for both the $\beta$ plane and $f$-plane calculations as follows. In the $\beta$-plane, the optimal filter window width was found by comparing the calculated $U_{\beta}$ to the current measured at the $0^{\circ} \mathrm{N}, 147^{\circ} \mathrm{E}$ Tropical Atmosphere Ocean/Triangle Trans Ocean Buoy Network (TAO/TRITON) mooring [McPhaden et al., 1998]. The best correlation ( $r=0.71)$ occurred for a full width at half maximum of $3.1^{\circ}$ (340 km) consistent with previous studies using SLA in the equatorial Pacific [Picaut et al., 1990; Delcroix et al., 1991]. A similar calculation was made in the $f$-plane using equation (2). The best correla-

tion $(r=0.68)$ between $U_{f}$ and along-coast current at the $142^{\circ} \mathrm{E}, 2.5^{\circ} \mathrm{E}$ ADCP mooring [Kuroda, 2000; Ueki et al., 2003] was found for a full width at half maximum of $0.7^{\circ}(80 \mathrm{~km})$ that allows resolving the coastal current.

The cross-track geostrophic current anomaly was calculated as the weighted sum of the geostrophic velocity anomaly in the $f$-plane away from the equator $\left(U_{f}\right)$ and of the $\beta$-plane geostrophic approximation $\left(U_{\beta}\right)$ near the equator following Lagerloef et al. [1999]:

$$
U_{g e o}=W_{\beta} U_{\beta}+W_{f} U_{f}
$$

where

$$
W_{\beta}=e^{\left(-\theta / \theta_{s}\right)^{2}}, W_{f}=1-W_{\beta}
$$

$\theta$ is the local latitude and $\theta_{s}$ is a latitudinal length scale set to $2.2^{\circ}$. The weight functions are applied to ensure a smooth transition between the equator and higher latitudes.

A monthly data set was constructed by averaging the 10 day data. The location of the surface boundary current as defined from this data set is shown in Figure 3. First, we detected the offshore maximum variability of the current anomaly along each track following Melet et al. [2010]. Then, the region where the standard deviation of the cross-track current anomaly is greater than half the maximum standard deviation determines the width of the coastal surface current. It forms a coherent coastal vein from Vitiaz Strait to the northern tip of New Guinea. In the following, time series of altimetric current anomaly are computed by averaging the current anomaly within the coastal current vein (darkened area of each track in Figure 3). Positive (negative) values represent southeastward (northwestward) current anomalies.

\subsection{Wavelet Analysis}

Wavelet analysis allows decomposing time series into the time-frequency space and gives information on how the amplitude and phase of harmonics of the time series vary in time. We use the Morlet wavelet analysis described in Torrence and Compo [1998] to document the variability of zonal wind stress, surface chlorophyll, and SST averaged over the zone of maximum variability of zonal wind stress and chlorophyll $\left(138^{\circ} \mathrm{E}-150^{\circ} \mathrm{E}\right.$, $6^{\circ} \mathrm{S}-1^{\circ} \mathrm{S}$; white box in Figure 2), as well as cross-track current anomalies. Wavelet spectra have been calculated over the period of availability of data (August 1991 to November 2009 for the zonal wind stress, September 1997 to December 2010 for SeaWiFS chlorophyll, January 1998 to December 2011 for TMI SST, January 1995 to December 2011 for AVHRR SST, and March 1993 to May 2011 for along-track altimetry). The resulting wavelet power spectra (Figure 4) indicate the time variations of the dominant modes of variability.

The wavelet analysis can also be used to isolate and reconstruct the signal in identified frequency bands. In this study, the intraseasonal, seasonal, and interannual signals of SST, surface chlorophyll, wind stress, and cross-track current anomaly shown in sections 4-6 are filtered from 20 to 120 days, 150 to 500 days, and above 500 days, respectively. 


\section{QAGU Journal of Geophysical Research: Oceans}
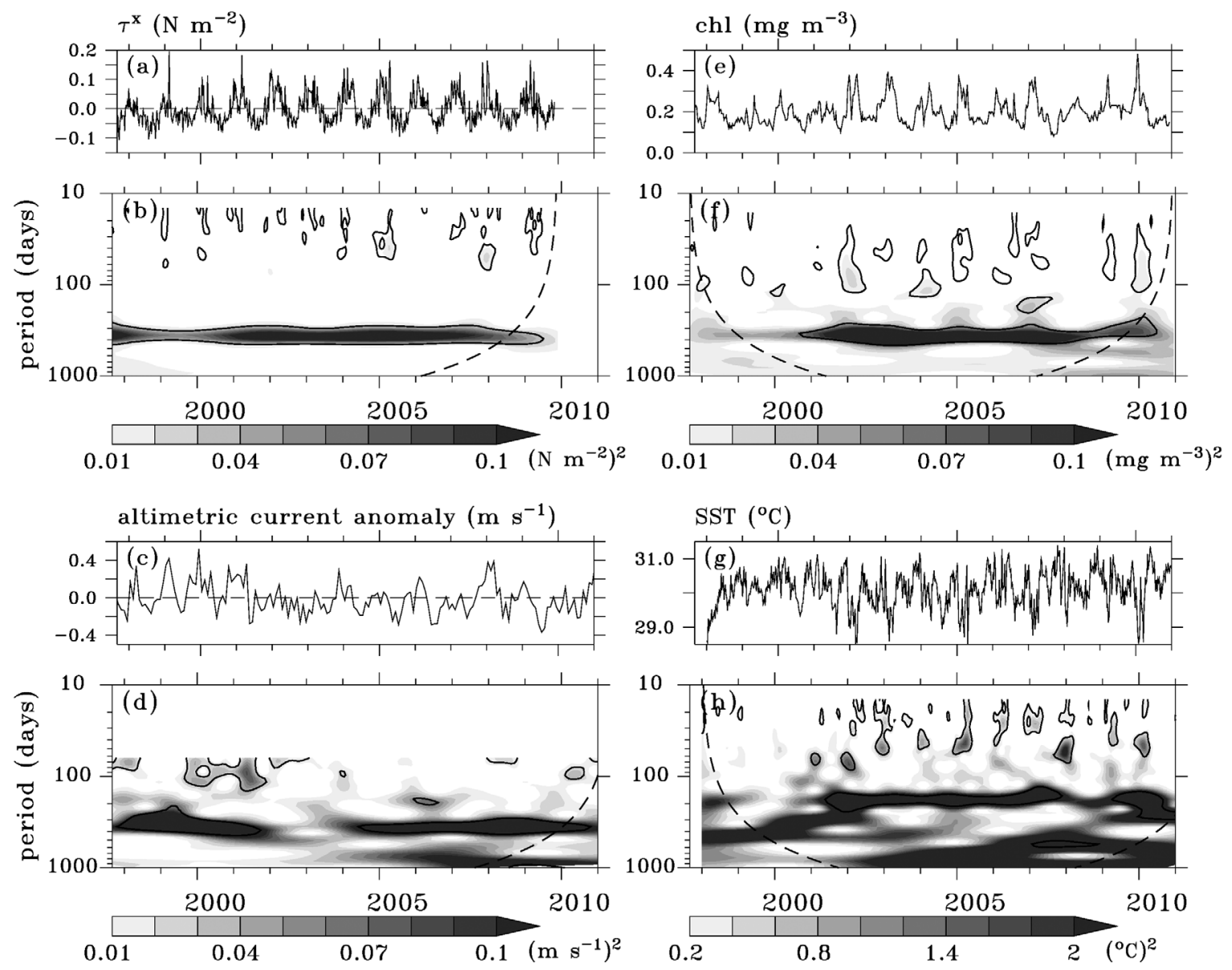

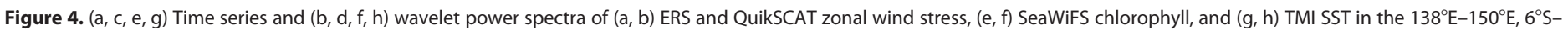

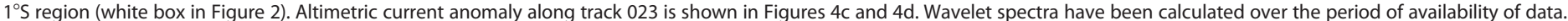

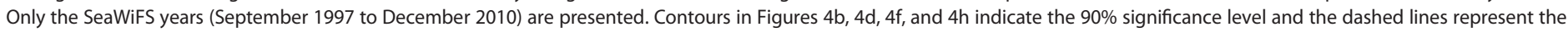
cone of influence below which edge effects are strong.

\section{Variability North of New Guinea}

The annual cycle observed in the zonal wind stress time series (Figure 4a) is highlighted in the wavelet spectrum by continuous maximum power in the annual frequency band (Figure 4b). Westerlies blow in austral summer and easterlies in winter (Figure 4a). They tend to be weak during La Niña years (1998-2001) and in late 1997 when WWEs have moved toward the central basin during the strong 1997-1998 El Niño event [Murtugudde et al., 1999; Boulanger et al., 2004]. Annual oscillations also dominate variations of the crosstrack geostrophic current anomaly (Figures $4 \mathrm{c}$ and $4 \mathrm{~d}$ ). The annual signal of the cross-track current anomaly is the strongest for the three tracks between Vitiaz Strait and $143^{\circ} \mathrm{E}$ (tracks 099, 023, and 201). The spectrum is shown for track 023. The current anomaly is mostly northwestward in winter and reverses in summer. Enhanced power is also found in the annual frequency band of the chlorophyll spectrum (Figure 4f). Chlorophyll concentrations (Figure 4e) are higher in austral summer (more than $0.3 \mathrm{mg} \mathrm{m}^{-3}$ ) than in winter (less than $0.2 \mathrm{mg} \mathrm{m}^{-3}$ ). The chlorophyll wavelet power tends to be weaker during La Niña years (1998-2001, 2008) when the summer peak is weaker. The SST wavelet power spectrum indicates a shift in the frequency of the signal (Figure 4h) between 1998 and 2000. The SST varies at the semiannual frequency except between 1998 and 2000 when oscillations are annual. SST minima occur in summer and winter, and amplitude variations are less than $1.5^{\circ} \mathrm{C}$ (Figure $4 \mathrm{~g}$ ). Local maxima of wavelet power are also seen in the 20-120 day frequency band of the zonal wind stress spectrum. They indicate bursts of intraseasonal wind variability associated with energetic episodic events of westerly winds, $79 \%$ of which occur between December and April. Patches of intraseasonal SST and chlorophyll variability are detected mostly in summer as well. In the 
(a) normalized power of $20-120-$ day $\tau^{\mathrm{x}}$, chl, TMI SST

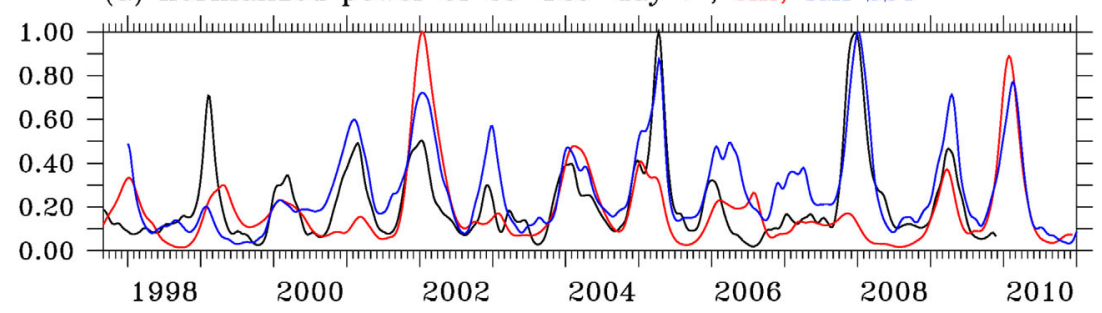

(b) running correlation of 20-120-day $\tau^{\mathrm{x}}$ vs. chl, $\tau^{\mathrm{x}}$ vs. SST

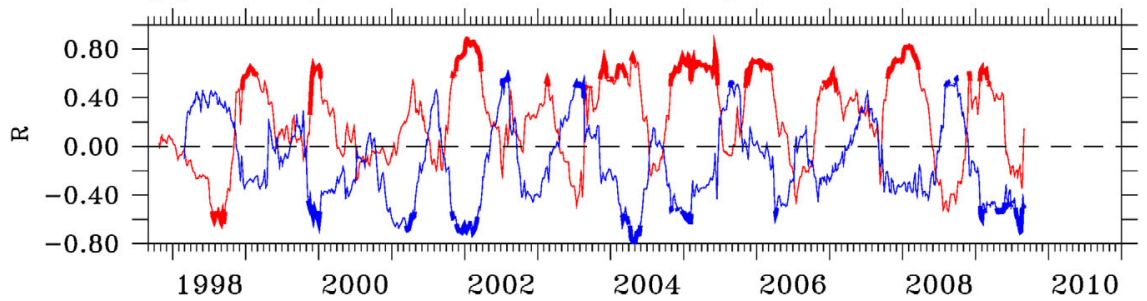

Figure 5. (a) Normalized wavelet power of zonal wind stress (black), chlorophyll (red), and TMI SST (blue) in the 20-120 day band in $138^{\circ} \mathrm{E}-150^{\circ} \mathrm{E}, 6^{\circ} \mathrm{S}-1^{\circ} \mathrm{S}$. (b) Running correlations in a 121 day window of intraseasonal zonal wind stress versus intraseasonal chlorophyll (red) and intraseasonal zonal wind stress versus intraseasonal TMI SST (blue). Correlations significant at the $95 \%$ level are indicated by thick lines.

following sections, we detail the spatial structure of the wind-driven responses of chlorophyll, SST, and surface circulation, and associated processes at the three time scales.

\section{Chlorophyll Response to Westerly Wind Events}

WWEs are well-known manifestations of intraseasonal atmospheric activity in the western equatorial Pacific. They generate an upwelling [Lukas and Lindstrom, 1991; Webster and Lukas, 1992] with low SST [Ueki et al., 2003; Delcroix et al., 2014] and enhanced biological production [Colin et al., 1973; Higgins et al., 2006] along the northern coast of New Guinea. The 20-120 day band-pass filtered time series of normalized wavelet power of zonal wind stress, chlorophyll, and SST in the $138^{\circ} \mathrm{E}-150^{\circ} \mathrm{E}, 6^{\circ} \mathrm{S}-1^{\circ} \mathrm{S}$ region are shown in Figure $5 \mathrm{a}$. Peaks of wavelet power indicate sustained intraseasonal activity during spring to fall and lessened activity in winter, in agreement with the seasonality of WWEs, whether they are associated with the Madden-Julian Oscillation (MJO), tropical cyclones, or other processes [Harrison and Vecchi, 1997; Lengaigne et al., 2004]. Running correlations (121 day window) between intraseasonal chlorophyll and zonal wind stress time series, and intraseasonal SST and zonal wind stress time series are presented in Figure 5b. Overall, strong positive (negative) relationship between chlorophyll (SST) and westerly wind occurs in summer. During these periods, positive correlations between chlorophyll and zonal wind stress over 0.7 and negative correlations between SST and zonal wind stress below -0.6 are significant at a $95 \%$ level of confidence [Sciremammano, 1979], highlighting the seasonal dependence of the link between chlorophyll, SST, and wind stress intraseasonal variations.

We built composite maps of wind stress, chlorophyll, SST, and current during the strongest WWEs to document spatial characteristics of the oceanic response. First, we identified weeks of occurrence of the $25 \%$ strongest westerly winds in the $138^{\circ} \mathrm{E}-150^{\circ} \mathrm{E}, 6^{\circ} \mathrm{S}-1^{\circ} \mathrm{S}$ region. We considered that WWEs were distinct when westerly events were separated by a 2 week recovery at least. This procedure results in 32 WWEs in the September 1997 to November 2009 period of time. Then, maps were constructed by averaging the closest available chlorophyll, SST, and current fields. Seven events were rejected because of strong cloudiness. The spatial chlorophyll pattern of the 25 remaining WWEs is characterized by phytoplankton-rich waters constrained south of the equator by wind and current convergences and the presence of the oligotrophic waters of the warm pool northward (Figure 6). These events were separated into two groups according to the eastward extension of chlorophyll-rich waters in the $2^{\circ} \mathrm{S}-0^{\circ} \mathrm{N}$ latitudinal band. The first group is composed of 19 events during which phytoplankton-rich waters do not spread east of New Ireland and a zonal convergence of surface current is observed at the eastern limit of chlorophyll-rich waters near $155^{\circ} \mathrm{E}$ (Figure 


\section{CAGU Journal of Geophysical Research: Oceans}

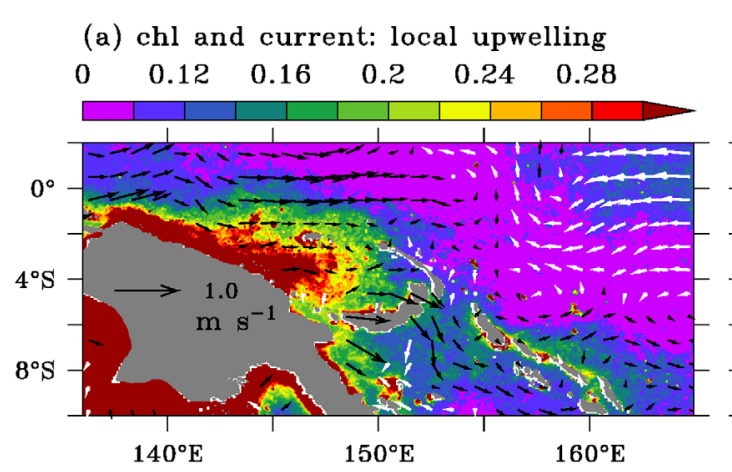

(b) chl and current: equatorial extension

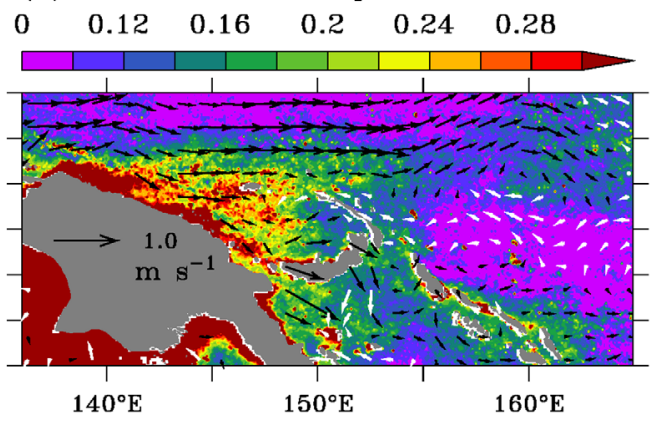

(c) SST and wind stress

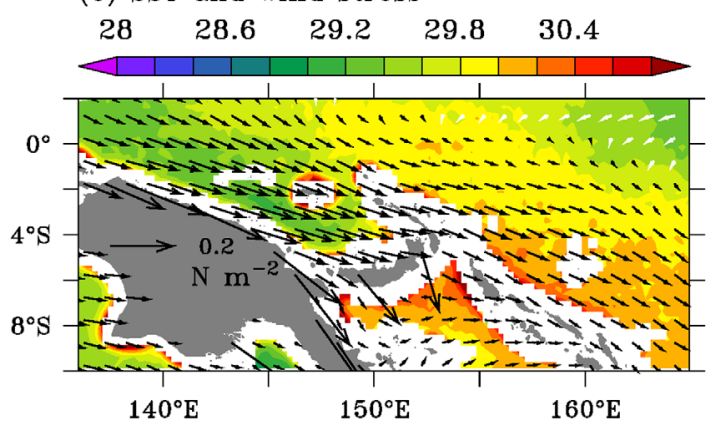

Figure 6. Composite WWE maps of SeaWiFS chlorophyll and OSCAR currents: (a) local upwelling, (b) equatorial extension, (c) TMI SST and QuikSCAT wind stress averaged during all WWE. Black (white) vectors indicate eastward (westward) wind stress and current.

6a). During the other WWEs (six events), chlorophyll-rich waters stretch east of New Ireland in the $2^{\circ} \mathrm{S}-0^{\circ} \mathrm{N}$ latitudinal band (Figure $6 \mathrm{~b}$ ) and chlorophyll concentration greater than $0.1 \mathrm{mg} \mathrm{m}^{-3}$ may reach $155^{\circ} \mathrm{E}-$ $162^{\circ}$ E. For all WWEs, the SST contrast between upwelled and warm pool waters is relatively modest and a coastal upwelling with no eastward expansion of cold waters shown in the composite of all WWE situations (Figure 6c) is representative.

Messie [2006] pointed out that chlorophyll-rich waters were transported toward the eastern equatorial warm pool during several WWEs of the onset and peak periods of the 2002-2003 El Niño, suggesting that nutrient-rich and chlorophyll-rich waters may be advected from the west by the wind-driven currents. Radenac et al. [2013] further showed the role of zonal advection in increasing chlorophyll concentrations in the equatorial warm pool during the SeaWiFS years (1998-2010). Figure 6b synthesizes such cases. But averaging the different situations that constitute this composite map results in current and chlorophyll data sets that are not totally consistent. Indeed, WWEs have different duration and fetch leading to chlorophyll-rich waters spreading to $160^{\circ} \mathrm{E}$ or maintained in the west. Besides, cloudiness is strong and weekly chlorophyll maps contain missing data. For that reason, the processes that lead to the surface chlorophyll pattern during WWE are further investigated through a case study.

During the December 2001 event, cloudiness allows resolving the main chlorophyll patterns that suggest horizontal advection processes. This event was relatively long lasting as northwesterly winds blew from early December 2001 to mid-January 2002. The maximum wind stress (about $0.12 \mathrm{~N} \mathrm{~m}^{-2}$ ) was sustained between 10 December and 8 January. A coastal upwelling developed, characterized by chlorophyll concentrations over $0.2 \mathrm{mg} \mathrm{m}^{-3}$ between the coast and the equator, eastward surface currents, a sea level depression, and coastal waters colder than $28.5^{\circ} \mathrm{C}$ [Messié, 2006]. The eastward spreading of phytoplankton-rich waters in the $0^{\circ} \mathrm{S}-2^{\circ} \mathrm{S}$ latitudinal band was coherent with the surface circulation field (Figure 7a).

We combined SeaWiFS chlorophyll and OSCAR surface currents to estimate the zonal $(-\mathrm{u} \partial[\mathrm{Chl}] / \partial \mathbf{x})$ and meridional ( $-\mathrm{v} \partial[\mathrm{Chl}] / \partial \mathrm{y})$ components of the chlorophyll horizontal advection and to evaluate their contributions to the mean chlorophyll temporal changes $(\partial[\mathrm{Chl}] / \partial \mathrm{t})$ in the $0^{\circ} \mathrm{N}-2^{\circ} \mathrm{S}$ band during the growing phase of chlorophyll changes related to the December 2001 WWE. The chlorophyll data were first interpolated onto the OSCAR grid $\left(1^{\circ} \times 1^{\circ}, 5\right.$ day). Then, the advection terms and $\partial[\mathrm{Chl}] / \partial \mathrm{t}$ were calculated at each 
(a) Dec. 2001 chlorophyll and current

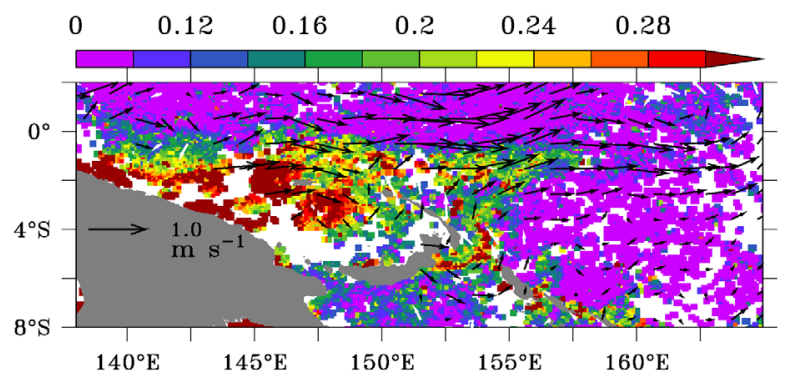

(b) chl temporal change and horizontal advection terms

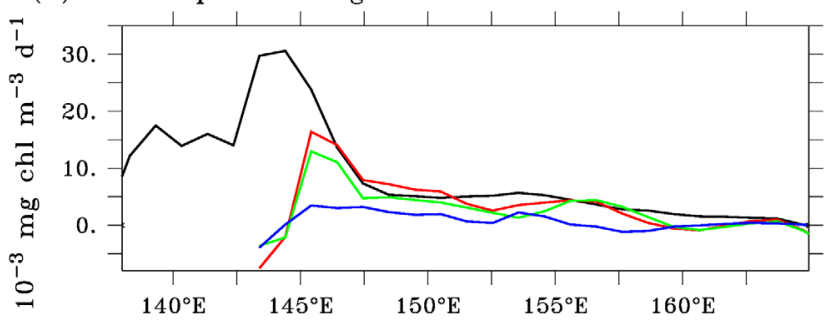

Figure 7. (a) SeaWiFS chlorophyll and OSCAR currents during the December 2001 WWE. Chlorophyll is a composite during the 8-31 December 2001 period of time. Current data are centered on 26 December. (b) Chlorophyll temporal changes (black), horizontal (red), zonal (green), and meridional (blue) advections, averaged between $0^{\circ} \mathrm{S}$ and $2^{\circ} \mathrm{S}$ in December 2001. phyll strongly increases while horizontal advection of chlorophyll is low. This strong difference results from rapid phytoplankton growth due to the upwelling of nutrient-rich waters along the coast and/or biological processes.

East of $146^{\circ} \mathrm{E}, \partial[\mathrm{Chl}] / \partial \mathrm{t}$ and horizontal advection tend to decrease similarly up to the approximate location of the eastern limit of mesotrophic waters near $160^{\circ} \mathrm{E}$. Zonal advection explains most of horizontal advection. The equatorial chlorophyll increase appears to result from the combination of coastal upwelling and sustained wind-driven equatorial currents in a way similar to the scenario proposed for SST cooling in response to WWEs [Lengaigne et al., 2002; Hasegawa et al., 2009]. Ekman currents advect coastal nutrientrich and phytoplankton-rich waters equatorward. Along the coast, a current convergence forms because of the reversal of the NGCC in the west of the region [Hasegawa et al., 2009, 2011] (see also section 5.2), and an associated northeastward flow contributes to the offshore transport; then, as the WWE develops, winddriven equatorial currents advect chlorophyll-rich waters eastward in the $0^{\circ} \mathrm{N}-2^{\circ} \mathrm{S}$ band. No significant vertical input of nutrient is expected when the water mass travels eastward because an equatorial downwelling is driven by the westerly wind. Biological processes slowly decrease the chlorophyll concentration. During the December 2001 WWE, zonal advection of nutrient-rich and chlorophyll-rich waters from the New Guinea upwelling contributes significantly to the chlorophyll increase observed in the equatorial oligotrophic warm pool.

\section{Seasonal Variations}

A monthly climatology was calculated from the reconstructed seasonal signals (150-500 days) between 2001 and 2010 (Figure 8). The seasonal cycles, contrasted spatial patterns during the northwest monsoon and the trade wind seasons, and associated processes are discussed in the following subsections.

Northwestward current anomaly during the southeast trade wind season in austral winter indicates an increase of the NGCC (Figure 8a). During summer, the wind reverses to northwest monsoon and altimetric current anomaly shifts to southeastward, representing a decrease or a reversal of the NGCC, consistent with the wind-driven seasonal variations derived from drifters, SADCP, and moorings. A reversal of the NGCC is observed west of the Sepik River during the northwest monsoon [Lindstrom et al., 1987; Kuroda, 2000; Mackey et al., 2002; Ueki et al., 2003; Dutrieux, 2009; Cravatte et al., 2011] while the surface flow is minimum 


\section{QAGU Journal of Geophysical Research: Oceans}

(a) along coast Ua 099, 023, 201

(b) $\tau^{\mathbf{x}}$, chl, AVHRR SST
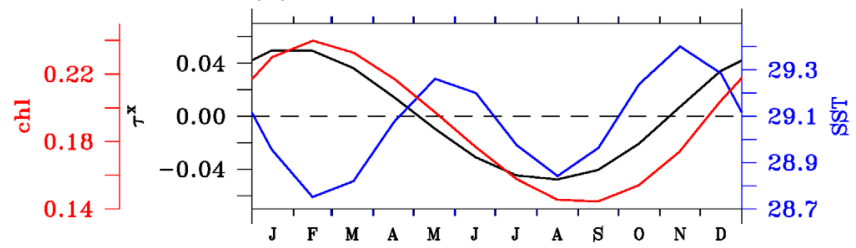

Figure 8. Climatology of the band-pass filtered time series using a 150-500 day wavelet filter. (a) Cross-track geostrophic current anomaly (Ua) for tracks 099 (black), 023 (red), and 201 (blue) along the northern coast of New Guinea. Positive (negative) values indicate southeastward (northwestward) current anomalies. (b) Zonal wind stress (black), chlorophyll (red), and AVHRR SST (blue) in $138^{\circ} \mathrm{E}-150^{\circ} \mathrm{E}$, $6^{\circ} \mathrm{S}-1^{\circ} \mathrm{S}$. Track 099 intersects the New Britain coast at $148.6^{\circ} \mathrm{E}$ and tracks 023 and 201 crosses the New Guinea coast at $146.2^{\circ} \mathrm{E}$ and $144^{\circ} \mathrm{E}$, respectively.

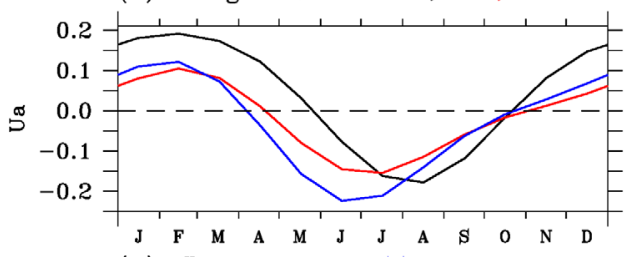

in Vitiaz Strait and does not reverse [Cravatte et al., 2011; Hristova and Kessler, 2012]. Seasonal variations of surface current anomalies in the Bismarck Sea (tracks 023 and 201) lead variations at the Vitiaz Strait entrance (track 099) by 1-2 months, especially during austral fall.

Chlorophyll increases and SST decreases when the wind is westerly (Figure 8b). Chlorophyll (SST) reaches its maximum (minimum) value in February. SST is relatively homogeneous $\left(\approx 28.3^{\circ} \mathrm{C}\right.$ ) almost all along the coast and slightly increases $\left(28.7^{\circ} \mathrm{C}\right)$ in the east (Figure 9a). A secondary SST minimum occurs in August when the wind is easterly. A stronger SST gradient is then observed along the coast with the coldest SST $\left(27.2^{\circ} \mathrm{C}\right)$ in Vitiaz Strait and the warmest SST in the west $\left(\approx 28.8^{\circ} \mathrm{C}\right)$. The austral summer SST minimum tends to be more intense than the winter minimum although the relative importance of SST minima changes interannually. Particularly, the summer minimum disappeared during the 1999, 2000, and 2001 La Niña years (not shown) when the eastern edge of the warm pool associated with high SST, low chlorophyll, and elevated SLA was displaced westward into the New Guinea region [Radenac et al., 2013]. Impacts of the Sepik and Mamberamo rivers are also seen in the longitude-time diagram of along coast chlorophyll concentration (high values near $138^{\circ} \mathrm{E}$ and $145^{\circ} \mathrm{E}$ in Figure $9 \mathrm{~b}$ ). Note that river plumes reach their westernmost location in August under the influence of the northwestward NGCC. In the following, we detail the ocean structures during the trade wind and northwest monsoon seasons.

\subsection{The Trade Wind Season (Austral Winter)}

The magnitude of the northwestward cross-track current anomaly (Figure 10b) is close to those of the seasonal anomaly of the drifter-estimated surface velocity [Hristova and Kessler, 2012, Figure 3] and of the SADCP measurements averaged along $142^{\circ} \mathrm{E}$ (Figure 11a). In situ observations report $0.5-1.0 \mathrm{~m} \mathrm{~s}^{-1}$ northwestward velocities in the upper layer of Bismarck Sea [Lukas et al., 1991; Kuroda, 2000; Mackey et al., 2002; (a) along coast $\mathrm{SST}$

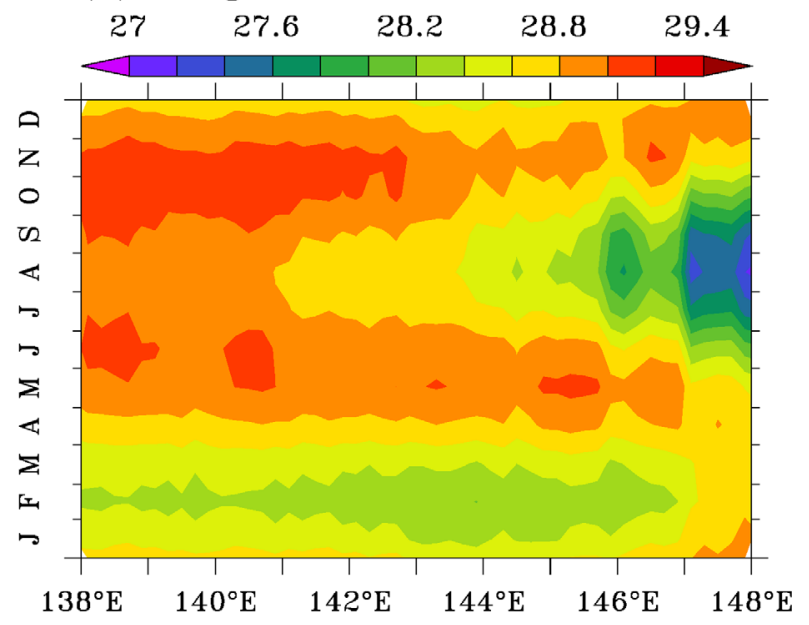

(b) along coast chl

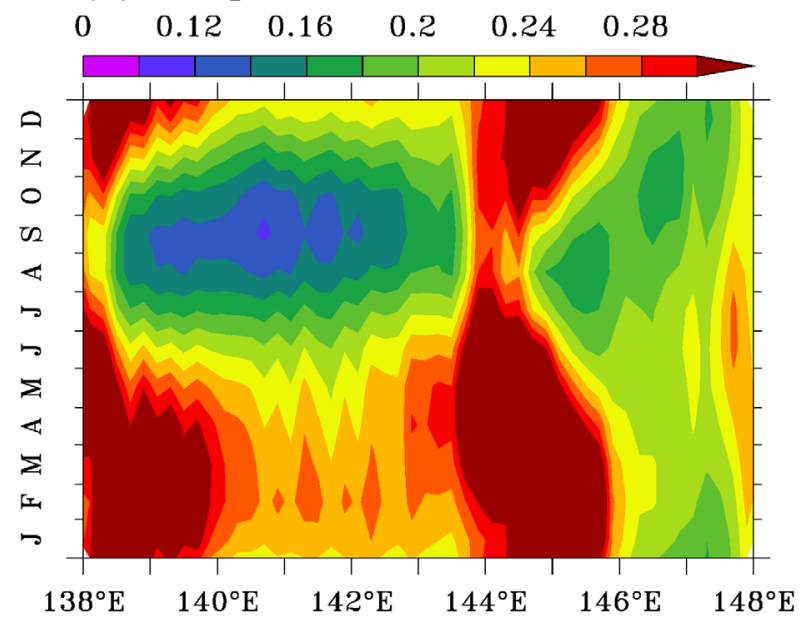

Figure 9. Climatology of seasonal along coast (a) SST $\left({ }^{\circ} \mathrm{C}\right)$ and (b) chlorophyll ( $\mathrm{mg} \mathrm{m}^{-3}$ ). Values are averaged within $1.5^{\circ}$ off the coast, from the northern tip of New Guinea $\left(138^{\circ} \mathrm{E}\right)$ to Vitiaz Strait $\left(148^{\circ} \mathrm{E}\right)$. 


\section{QAGU Journal of Geophysical Research: Oceans}

August

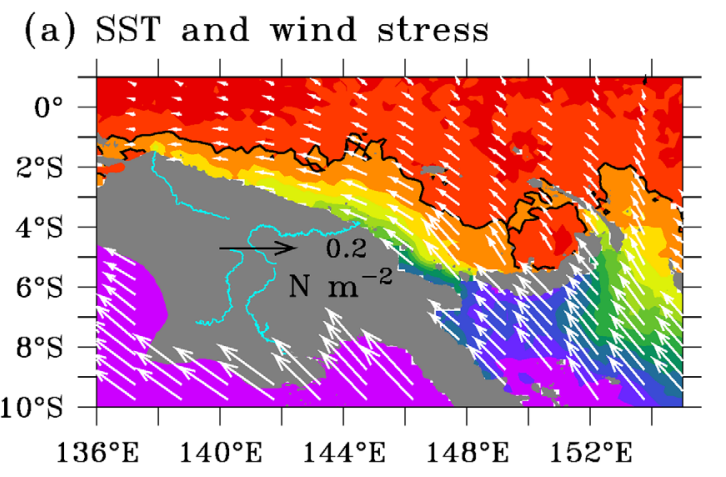

(b) chlorophyll and current anomaly

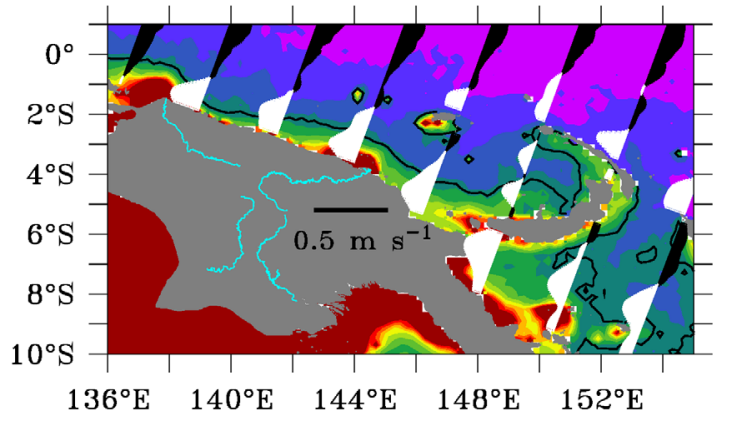

February

(c) SST and wind stress

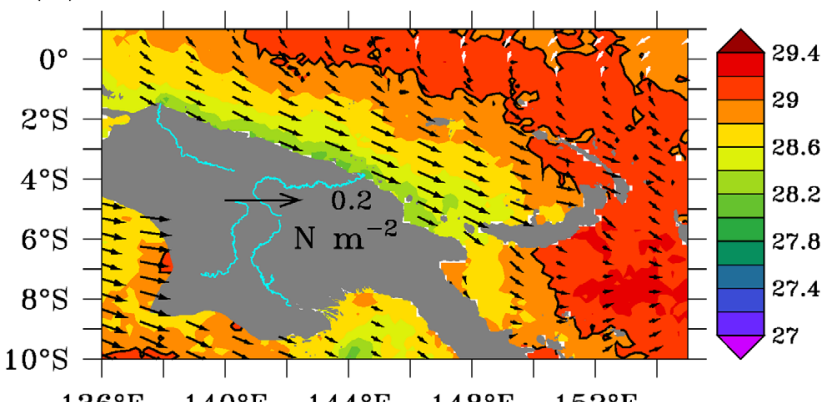

$136^{\circ} \mathrm{E} \quad 140^{\circ} \mathrm{E} \quad 144^{\circ} \mathrm{E} \quad 148^{\circ} \mathrm{E} \quad 152^{\circ} \mathrm{E}$

(d) chlorophyll and current anomaly

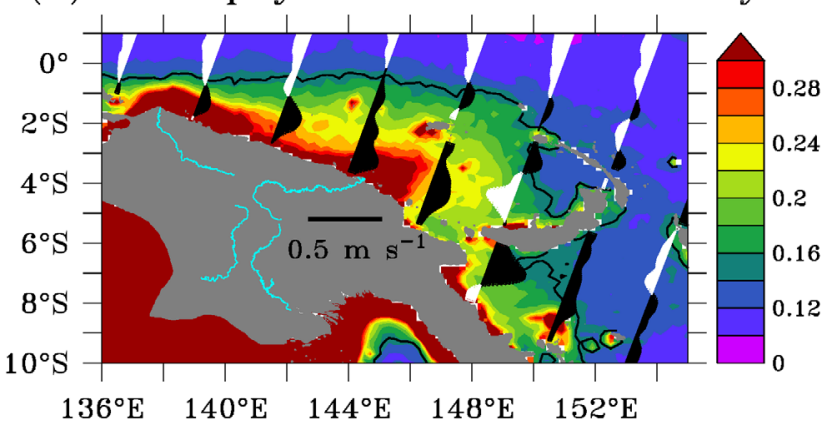

Figure 10. Maps of seasonal $(\mathrm{a}, \mathrm{c}) \mathrm{SST}\left({ }^{\circ} \mathrm{C}\right)$ and wind stress $\left(\mathrm{N} \mathrm{m}^{-2}\right)$ and $(\mathrm{b}, \mathrm{d})$ surface chlorophyll $\left(\mathrm{mg} \mathrm{m}^{-3}\right)$ and altimetric cross-track current anomaly $\left(\mathrm{m} \mathrm{s}{ }^{-1}\right)$ in $(\mathrm{a}, \mathrm{b})$ August and $(\mathrm{c}, \mathrm{d})$ February. Black (white) vectors indicate eastward (westward) wind stress and current anomaly. Black contours are the $29^{\circ} \mathrm{C}$ isotherm and $0.15 \mathrm{mg} \mathrm{m}^{-3} \mathrm{chlorophyll}$ isoline.

Ueki et al., 2003] and a much stronger flow (1.1-1.8 $\mathrm{m} \mathrm{s}^{-1}$ ) in Vitiaz Strait [Lindstrom et al., 1990; Murray et al., 1995; Cresswell, 2000; Eldin et al., 2013], the width of which is less than $50 \mathrm{~km}$. The high along-track resolution of the altimetric current anomaly allows describing the nearshore structure of the surface current. The coastal current vein is $120 \mathrm{~km}$ wide east of Vitiaz Strait (track 099) and 100-200 km west of the strait (Figure 10b). It is the widest (near $200 \mathrm{~km}$ ) along tracks 023 and 201 in agreement with the surface current issued from the $1 / 12^{\circ}$ Ocean General Circulation Model (OGCM) [Delcroix et al., 2014] developed by the DRAKKAR group [Gourdeau et al., 2014]. A southwestward flow entering the Bismarck Sea between Manus Island and New Ireland merges with the along-coast current at this location in winter. West of Vitiaz Strait, the seasonal current anomaly is maximum 100-150 km offshore and strongly weakens near the coast as suggested by mooring observations at $142^{\circ} \mathrm{E}$ [Ueki et al., 2003] and cruise measurements (Figure 11a) [Cresswell, 2000; Mackey et al., 2002]. East of Vitiaz Strait (track 099), the core of the current anomaly is less than $100 \mathrm{~km}$ off the southern coast of New Britain as observed by Cravatte et al. [2011] and Hristova and Kessler [2012].

The energetic northwestward flow in Vitiaz Strait funnels cold surface waters from the Solomon Sea into the Bismarck Sea. West of Vitiaz Strait, this forms a narrow vein (100-150 km wide) of cold water following the core of the NGCC (Figure 10a). Its northern limit is characterized by a meridional gradient that can reach $0.6^{\circ} \mathrm{C}-0.8^{\circ} \mathrm{C}$ per degree latitude. Most of the SST variability in the Solomon Sea is explained by a strong annual cycle with coldest waters in August [Delcroix et al., 2014]. The cold coastal tongue develops when the NGCC increases and Solomon Sea SST decreases, and it reaches its maximum expansion in August. At that time, coldest coastal waters (lower than $28^{\circ} \mathrm{C}$ ) in the Bismarck Sea are found west of Vitiaz Strait. They warm gradually along the NGCC path, SST reaching $28.8^{\circ} \mathrm{C}$ at $141^{\circ} \mathrm{E}$.

In the open ocean, lowest surface chlorophyll concentrations are observed during the trade wind season (Figure 10b). Chlorophyll above $0.25 \mathrm{mg} \mathrm{m}^{-3}$ is found very close to the coast and in the Sepik and Mamberamo plumes. Relatively high values are probably biased because of particulate matter [Milliman et al., 1999] although the river discharge and rainfall are the lowest in winter [Smith et al., 2013; Delcroix et al., 2014]. 


\title{
QAGU Journal of Geophysical Research: Oceans
}

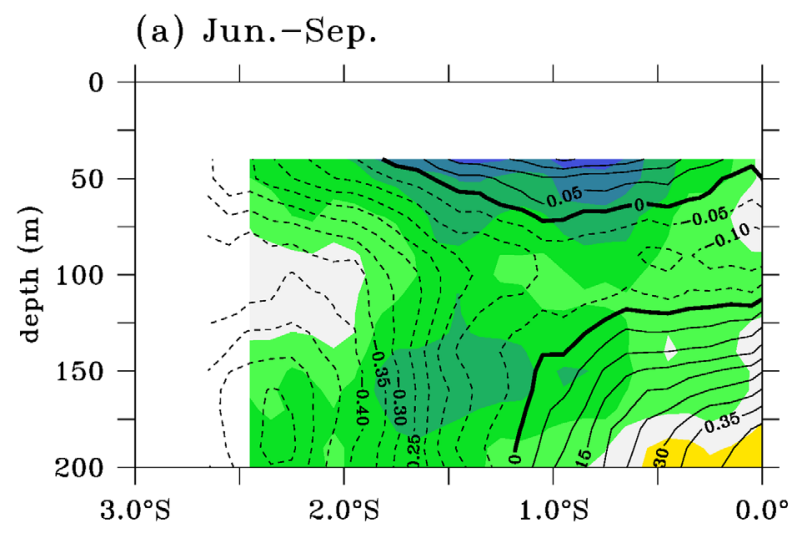

\author{
(b) Dec. - Feb.
}

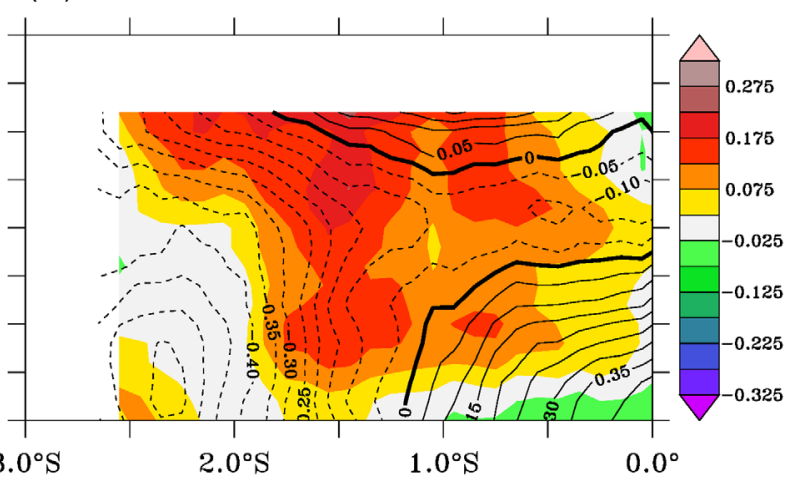

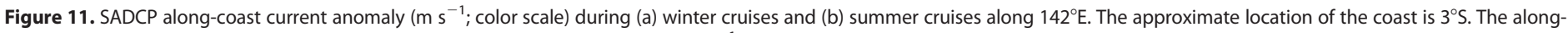
coast current averaged during the 13 cruises is overlaid. Contours are every $0.05 \mathrm{~m} \mathrm{~s}^{-1}$.

However, high nitrate and chlorophyll concentrations were measured at coastal stations while oligotrophic conditions (low chlorophyll and nitrate-depleted surface layer, deep chlorophyll maximum, and numerous Prochlorococcus) similar to those of the western equatorial Pacific prevailed in the central Bismarck Sea [Colin et al., 1973; Higgins et al., 2006]. In contrast with the SST situation, no clear penetration of Solomon Sea waters into the Bismarck Sea is observed as chlorophyll concentrations are similar on both sides of the strait.

\subsection{The Northwest Monsoon Season (Austral Summer)}

The core of the coastal current anomaly is located about $50 \mathrm{~km}$ further north than during the trade wind season. The current anomaly is southeastward from Vitiaz Strait to $138^{\circ} \mathrm{E}$ representing a weakening or reversal of the surface current (Figure 10d) as measured by drifters [Hristova and Kessler, 2012] and SADCP (Figure $11 \mathrm{~b})$. Southeastward velocities between 0.4 and $0.8 \mathrm{~m} \mathrm{~s}^{-1}$ have been measured in the coastal current west of $145^{\circ} \mathrm{E}$ [Wyrtki, 1961; Masuzawa 1967, 1968; Colin et al., 1973; Lindstrom et al., 1987; Kuroda, 2000; Mackey et al., 2002; Ueki et al., 2003]. In Vitiaz Strait, SADCP climatology [Cravatte et al., 2011], drifters [Hristova and Kessler, 2012], and current meter moorings deployed between February 1992 and April 1993 [Murray et al., 1995] indicate that the northwestward surface flow does not reverse seasonally but is strongly reduced. One instance of current reversal was nonetheless observed in February 1986 [Lindstrom et al., 1990]. The southeastward coastal current in the west and the northwestward flow exiting from Vitiaz Strait create a convergence near the Sepik River mouth. This convergence is reproduced in the OGCM for the Earth Simulator (OFES) simulation [Hasegawa et al., 2011] and in the DRAKKAR 1/12 OGCM [Gourdeau et al., 2014] where it generates an offshore flow [Hasegawa et al., 2011; Delcroix et al., 2014] that shapes the surface chlorophyll pattern off the Sepik River (Figure 10d).

The northwesterly wind, alongside the coast, is favorable to coastal upwelling (Figure 10c) [Colin et al., 1973; Lukas, 1988]. Its impact on surface temperature remains moderate; coastal SST is between $28.2^{\circ} \mathrm{C}$ and $28.6^{\circ} \mathrm{C}$ (Figures $10 \mathrm{C}$ and $9 \mathrm{a}$ ) which is about $1{ }^{\circ} \mathrm{C}$ less than the surrounding waters of the warm pool. This could result from an inefficient upwelling as cruise observations suggest that water is upwelled from 50 to $100 \mathrm{~m}$ [Colin et al., 1973; Kuroda, 2000; Ueki et al., 2003; Hasegawa et al., 2009], i.e., slightly above the top of the thermocline (80-100 m) [Lukas and Lindstrom, 1991].

The phytoplankton-rich zone with chlorophyll concentration over $0.15 \mathrm{mg} \mathrm{m}^{-3}$ extends from the coast to the equator (Figure 10d). Oligotrophic waters of the warm pool $\left(\mathrm{chl}<0.1 \mathrm{mg} \mathrm{m}^{-3}\right)$ are found northward. The northern limit of the high chlorophyll region, oriented west-east near the equator, is consistent with the presence of a meridional current convergence driven by westerly winds on the equator. Chlorophyll remains above $0.20 \mathrm{mg} \mathrm{m}^{-3}$ between December and May (Figure 9b) when the macronutrients and micronutrients are upwelled from the upper part of the NGCUC to the euphotic layer allowing phytoplankton growth. Away from the river influence, chlorophyll concentration is higher than in winter and nanoplankton dominates the phytoplankton community [Colin et al., 1973; Everitt et al., 1990; Higgins et al., 2006]. Riverine input may also impact the biological production [Higgins et al., 2006]. The strongest water discharge of the Sepik River in March-April follows the maximum rainfall over the catchment area by a short time-lag [Delcroix et al., 2014] 
(a) $\tau^{\mathrm{x}}$ SLA SOI

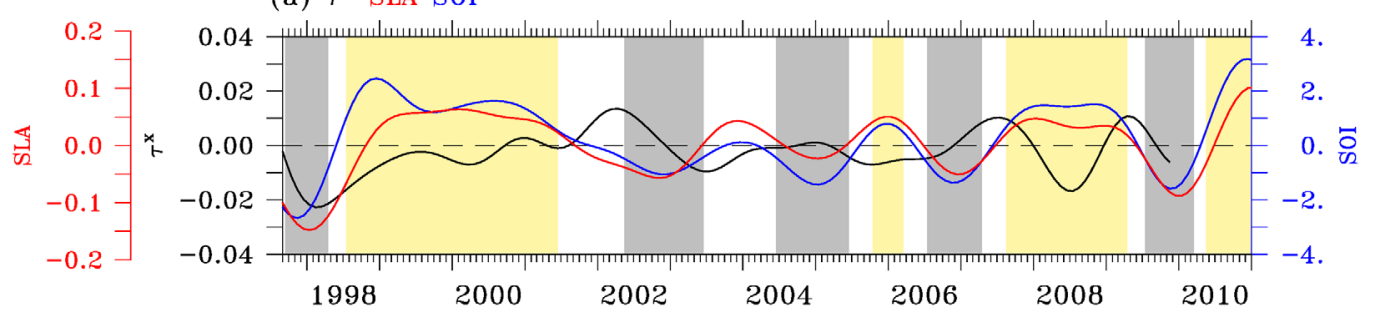

(b) AVHRR SST chl

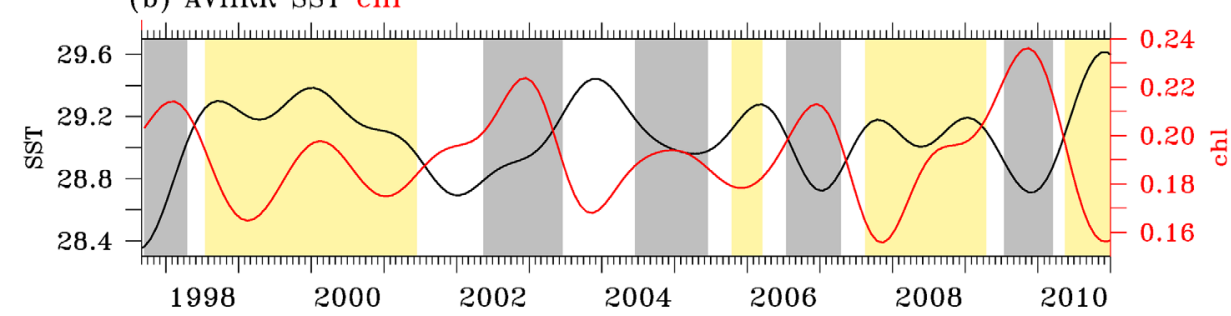

(c) along coast UaI 099023201251

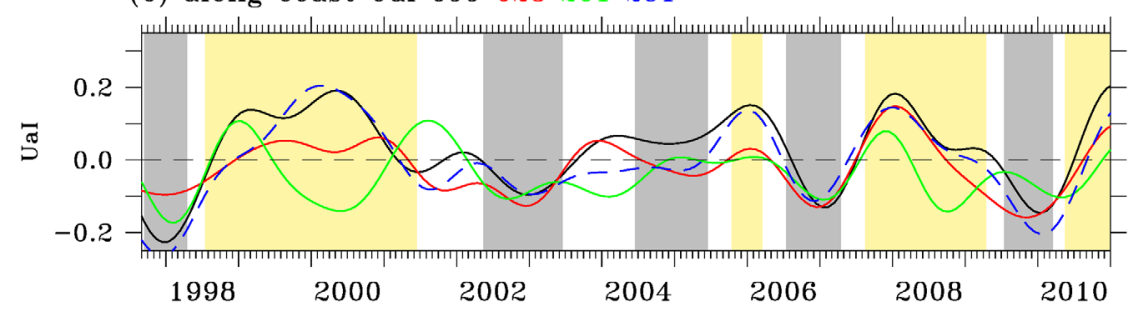

(d) along coast UaI 125049 and Ua $160^{\circ} \mathrm{E}, 0^{\circ}$

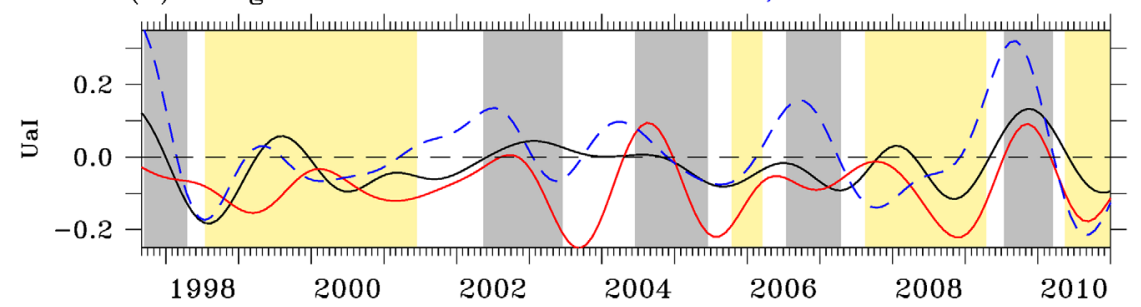

Figure 12. Interannual variations of (a) zonal wind stress (black) in the $138^{\circ} \mathrm{E}-150^{\circ} \mathrm{E}, 6^{\circ} \mathrm{S}-1^{\circ} \mathrm{S}$ region, coastal SLA (red), and SOI (blue); (b) AVHRR SST (black) and SeaWiFS chlorophyll (red) in the $138^{\circ} \mathrm{E}-150^{\circ} \mathrm{E}, 6^{\circ} \mathrm{S}-1^{\circ} \mathrm{S}$ region; (c) altimetric cross-track current anomaly (Ual) in the NGCC for tracks 099 (black), 023 (red), 201 (green), and 251 (Solomon Sea; dash blue). The altimetric current anomaly in the Solomon Sea is calculated in the NGCC pathway near Woodlark [Melet et al., 2010]; (d) cross-track current anomaly (Ual) in the NGCC for tracks 125 (black), 049 (red), and gridded AVISO geostrophic current anomaly at $160^{\circ} \mathrm{E}, 0^{\circ}$ (dash blue). Grey (yellow) shading indicates El Niño (La Niña) periods. Track 099 intersects the New Britain coast at $148.6^{\circ} \mathrm{E}$, and tracks 023, 201, 125, and 046 crosses the New Guinea coast at $146.2^{\circ} \mathrm{E}, 144^{\circ} \mathrm{E}, 141.5^{\circ} \mathrm{E}$, and $138.9^{\circ} \mathrm{E}$, respectively.

and is almost twice the minimum discharge in August-September [Kineke et al., 2000; Delcroix et al., 2014]. The high river flow impacts the expansion of the river plume and high coastal chlorophyll concentrations (more than $0.5 \mathrm{mg} \mathrm{m}^{-3}$ ) are observed in the river plumes within 100-150 km off the coast. Sepik and Mamberamo river plumes are deflected eastward. No cold or chlorophyll-rich waters are clearly observed east of Vitiaz Strait, further suggesting that the NGCC does not reverse there at the seasonal time scale.

\section{Interannual Variations}

Interannual variations (above 500 days) of zonal wind stress, chlorophyll, and SST in the $138^{\circ} \mathrm{E}-150^{\circ} \mathrm{E}, 6^{\circ} \mathrm{S}-$ $1^{\circ} \mathrm{S}$ zone, together with current anomaly deduced from along-track altimetry in the NGCC region are presented in Figure 12. Interannual coastal SLA in Figure 12a is calculated in the same region than altimetric currents (darken zones in Figure 3). Time series of the altimetric current anomaly in the Solomon Sea at the 


\section{QDAU Journal of Geophysical Research: Oceans}

El Nino

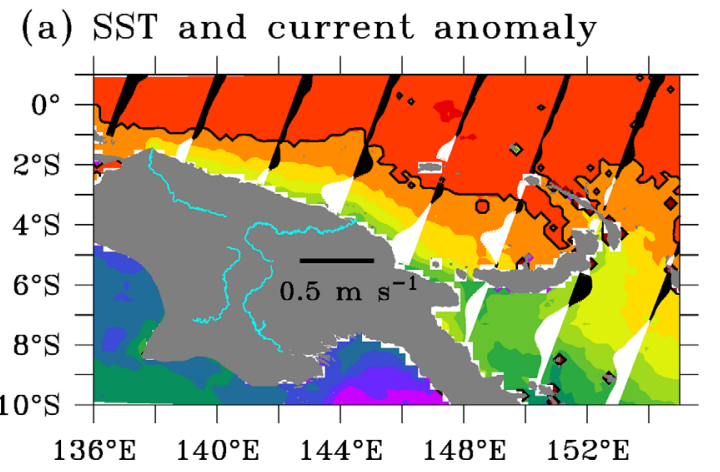

(c) chlorophyll and current anomaly

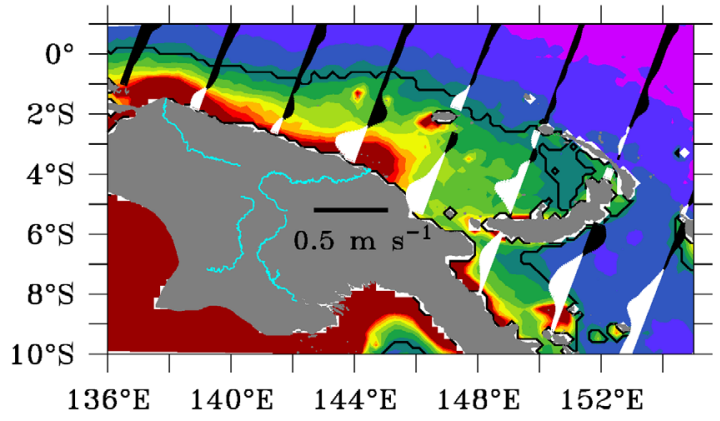

La Nina

(b) SST and current anomaly

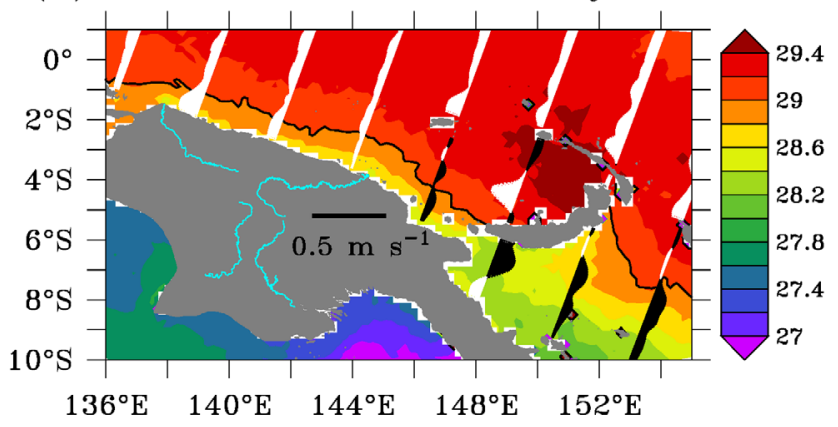

(d) chlorophyll and current anomaly

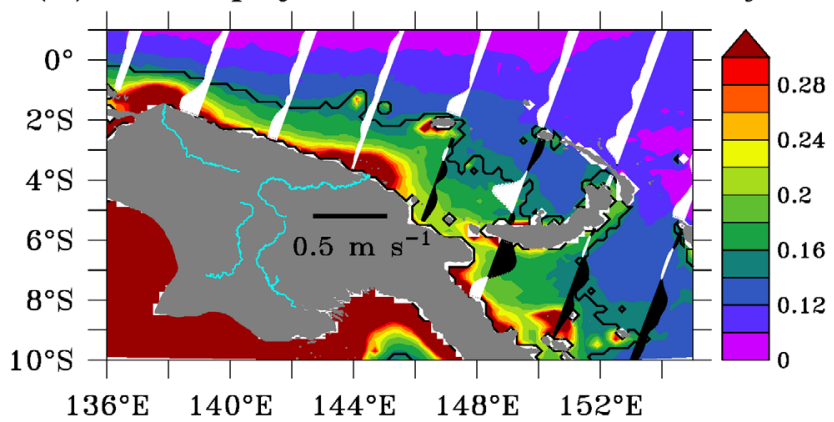

Figure 13. Maps of $(\mathrm{a}, \mathrm{b}) \mathrm{SST}\left({ }^{\circ} \mathrm{C}\right)$ and $(\mathrm{c}, \mathrm{d})$ surface chlorophyll $\left(\mathrm{mg} \mathrm{m}^{-3}\right)$ during $(\mathrm{a}, \mathrm{c})$ El Niño and $(\mathrm{b}, \mathrm{d})$ La Niña. Altimetric cross-track current anomaly ( $\left.\mathrm{m} \mathrm{s}{ }^{-1}\right)$ is overlaid. Black (white) vectors indicate eastward (westward) current anomaly. Black contours are the $29^{\circ} \mathrm{C}$ isotherm and $0.15 \mathrm{mg} \mathrm{m}^{-3}$ chlorophyll isoline.

eastern tip of Woodlark island (region A1 in Melet et al. [2010] is track 251 in Figure 12c) and of the AVISO geostrophic current anomaly at the equator (Figure 12d) are also shown. We construct composites of the interannual signal of chlorophyll, SST, and altimetric current anomaly (Figure 13) in order to analyze their spatial patterns during El Niño and La Niña. El Niño (La Niña) composites are built by averaging monthly situations during which SOI is lower (greater) than -0.4 (0.4). El Niño and La Niña episodes detected using these thresholds are consistent with warm and cold phases based on other indices such as the Oceanic Niño Index (ONl; http://www.cpc.ncep.noaa.gov/products/analysis_monitoring/ensostuff/ensoyears.shtml).

Five El Niño events were observed during the SeaWiFS years: the peak period of the strong 1997-1998 event and four moderate events in 2002-2003, 2004-2005, 2006-2007, and 2009-2010 (Figure 12a). La Niña conditions prevailed from mid-1998 to mid-2001, from mid-2007 to mid-2009, and in the second half of 2010. The wind north of New Guinea is westward during La Niña. During El Niño, it is slightly eastward during the onset period and shifts to westward when the convection zone and the associated westerly wind move toward the central Pacific. SLA along the equatorial coast of New Guinea varies in the same way as SLA in the western Pacific (not shown) in agreement with the basin-wide zonal tilt of the thermocline and nutricline at the El Niño Southern Oscillation (ENSO) time scale: the nutricline is shallower during El Niño years and deeper during La Niña.

The extent of the high chlorophyll and low SST region (Figures 13a and 13c) is larger than average during El Niño. The $0.15 \mathrm{mg} \mathrm{m}^{-3}$ chlorophyll isoline is situated slightly south of its summer location (February; Figure $10 \mathrm{~d}$ ) and the $29^{\circ} \mathrm{C}$ isotherm is near its winter location (August; Figure 10a). During La Niña, the area of high chlorophyll and low SST water is close to average in terms of chlorophyll and smaller than average in terms of SST (Figures 13b and 13d). Overall, surface chlorophyll increases (decreases) and SST is cooler (warmer) during El Niño (La Niña; Figure 12b). Both the upwelling and penetration of Solomon Sea waters seem to contribute to interannual variations of SST and chlorophyll during El Niño. The southern part of the Solomon Sea is $0.5^{\circ} \mathrm{C}-1{ }^{\circ} \mathrm{C}$ colder than the Bismarck Sea and cooling from the Solomon Sea spreads in the Bismarck Sea along the intensified NGCC path. It results in SST patterns resembling the trade wind situation. 
Table 1. Correlation Coefficients Between (First Line) the Interannual CrossTrack Current Anomalies (Ual) in the Bismarck Sea and in the Solomon Sea Sections of the NGCC and (Second Line) the Interannual Cross-Track Current Anomalies in the Bismarck Sea and the AVISO Interannual Zonal Current Anomaly at $160^{\circ} \mathrm{E}, 0^{\circ}$

\begin{tabular}{lrrrrr} 
& Ual 049 & Ual 125 & Ual 201 & Ual 023 & Ual 099 \\
\hline NGCC Solomon Sea & -0.20 & -0.27 & 0.22 & 0.79 & 0.93 \\
$160^{\circ} \mathrm{E}, 0^{\circ} \mathrm{N}$ & 0.41 & 0.59 & -0.16 & -0.58 & -0.49 \\
\hline
\end{tabular}

A similar process tends to bring low chlorophyll waters west of Vitiaz Strait. Meanwhile, slightly more numerous WWEs and shallower thermocline and nutricline drive a coastal upwelling. Both upwelling and penetration of Solomon Sea waters therefore likely combine to lower SST and have opposing and counteracting effects on chlorophyll. The El Niño chlorophyll pattern is similar to that observed in summer when the upwelling is active while the SST pattern is reminiscent of the coastal cold tongue observed in winter. During La Niña, both processes appear to be less efficient; warm pool waters largely encroach on Bismarck Sea (Figure 13b), and the extension of chlorophyll-rich waters is moderate (Figure 13d).

Separated at the coast at about $143^{\circ} \mathrm{E}$, two groups of altimetric current anomaly with opposite signs can be distinguished at the interannual time scale. During El Niño, the magnitude of the northwesward current anomaly strongly diminishes between the easternmost (099, 023, and 201; Figures 12c, 13a, and 13c) and westernmost (125 and 049; Figures 12d, 13a, and 13c) tracks, leading to a convergence between the two regions. Inversely, current anomalies diverge during La Niña, with current anomaly reversing to southeastward east of $143^{\circ} \mathrm{E}$. Current anomaly variations east of Vitiaz Strait (track 099) are very close to variations of the NGCC in the Solomon Sea (track 251) where it intensifies during El Niño and weakens during La Niña [Melet et al., 2010]. Variations of the flow west of the strait are correlated with those of the NGCC Solomon sector (Figure 12c). In the northwestern part between $138^{\circ} \mathrm{E}$ and $142^{\circ} \mathrm{E}$ (Figure $12 \mathrm{~d}$ ), the relationship with the flow from the Solomon Sea vanishes while that of the equatorial flow (represented by the current anomaly of the gridded AVISO product) increases (Table 1). The variability of the NGCC near the Sepik River mouth (track 201, close to the convergence/divergence zone) is poorly explained by variations of the NGCC in the Solomon Sea or of the equatorial flow. These low correlations reflect the complex surface circulation; variability of the St. Georges's Channel flow [Cravatte et al., 2011], of the South Equatorial Current flow [Hristova and Kessler, 2012; Delcroix et al., 2014], and recirculation in the eastern Bismarck Sea [Hasegawa et al., 2009, 2011] may combine to influence the magnitude of the coastal current in this area.

\section{Discussion and Concluding Remarks}

Variations of wind, surface coastal circulation, SST, and chlorophyll deduced from satellite observations at the intraseasonal to interannual time scales in the western tropical Pacific, north of New Guinea, are summarized in Table 2. Two main processes, namely coastal upwelling and penetration of Solomon Sea waters, appear to contribute to shaping SST and surface chlorophyll patterns. These and other processes are further discussed below.

\subsection{Coastal Upwelling}

A coastal upwelling develops when the wind is westerly (WWE, austral summer, and El Niño). Then, elevated chlorophyll $\left(>0.15 \mathrm{mg} \mathrm{m}^{-3}\right.$ ) in the upwelled coastal waters contrasts with the low chlorophyll waters of the oligotrophic warm pool. The meridional spreading of phytoplankton-rich waters stops near the equator because of wind and current convergence. In contrast, the upwelling impact on SST is moderate and coastal waters are less than $1^{\circ} \mathrm{C}$ cooler than warm pool waters.

\begin{tabular}{|c|c|c|c|c|c|c|}
\hline & $\begin{array}{c}\text { Wind } \\
\text { Direction }\end{array}$ & $\begin{array}{l}\text { Current Anomaly } \\
\text { West of Sepik }\end{array}$ & $\begin{array}{c}\text { Current Anomaly } \\
\text { East of Sepik }\end{array}$ & SST Anomaly & $\begin{array}{c}\text { Chlorophyll } \\
\text { Anomaly }\end{array}$ & Processes \\
\hline WWE & $\searrow$ & $\searrow$ & & $<0$ & $>0$ & UPW \\
\hline austral summer & $\searrow$ & $\searrow$ & $\searrow$ & $<0$ & $>0$ & UPW \\
\hline austral winter & $\nwarrow$ & $\nwarrow$ & $\nwarrow$ & $<0$ & $<0$ & $\mathrm{CCT}$ \\
\hline El Niño & $\searrow$ & $\approx 0$ & $\nwarrow$ & $<0$ & $>0$ & UPW and CCT \\
\hline La Niña & $\nwarrow$ & $\nwarrow$ & $\searrow$ & $>0$ & $<0$ & \\
\hline
\end{tabular}

${ }^{a}$ UPW stands for upwelling and CCT for coastal cold tongue. 
Coastal variations of SST and chlorophyll differ during the northwest monsoon season and during El Niño. This difference may be partially explained by a simple upwelling model. Assuming that vertical advection is the main driver of SST variations, local wind-driven changes of SST depend on upwelling velocity and temperature stratification $(\tau / / / p f L)(\partial T / \partial z)$, where $\tau /$ is the along-coast component of the wind stress, $\rho$ is the sea water density, $f$ is the Coriolis parameter, and $L$ is a cross-shore length scale characteristic of the coastal divergence region. The continental shelf is narrow north of New Guinea and the slope is steep (Figure 1). In such a case, $L$ is the width of the lateral Ekman layer $\pi \sqrt{2 A_{H} /|f|}[$ Marchesiello and Estrade, 2010]. If the lateral eddy viscosity $A_{H}$ varies between 10 and $100 \mathrm{~m}^{2} \mathrm{~s}^{-1}$, the dynamical upwelling occurs in a narrow coastal region 4-12 km wide. Assuming that $L$ is $12 \mathrm{~km}$, the vertical velocity generated by the along-coast wind stress $\left(\approx 0.01 \mathrm{~N} \mathrm{~m}^{-2}\right)$ during El Niño is $5.7 \mathrm{~m} \mathrm{~d}^{-1}$. The vertical temperature gradient, $\partial T / \partial z$, can be estimated between the surface and the upwelling depth (around $80 \mathrm{~m}$ ) [Colin et al., 1973]. Since Variations of the thermocline depth are highly correlated with variations of SLA in the western equatorial Pacific and the ratio between variations of SLA and thermocline depth is near 1/200 in the western equatorial Pacific [Rébert et al., 1985; Turk et al., 2001], a 0.1 m SLA decrease during El Niño corresponds to a $20 \mathrm{~m}$ thermocline uplift. Temperature at the upwelling depth during El Niño can then be estimated by shifting $20 \mathrm{~m}$ upward the mean temperature profile of the CSIRO Atlas of Regional Seas (CARS) [Ridgway et al., 2002], and the vertical temperature gradient estimated using the SST derived from the wavelet analysis. Following these assumptions, the cooling due to vertical advection during El Niño is estimated at $0.14^{\circ} \mathrm{C} \mathrm{d}^{-1}$ in the coastal band. At the seasonal time scale, the same argument would lead to cooling twice as large $\left(0.3^{\circ} \mathrm{C}^{-1}\right)$ in February because of a larger vertical velocity and despite a smaller stratification. A similar model for the nitrate supply to the surface yields vertical rates around $0.29 \mu \mathrm{mol} \mathrm{L}^{-1} \mathrm{~d}^{-1}$ during El Niño and 2.7 times

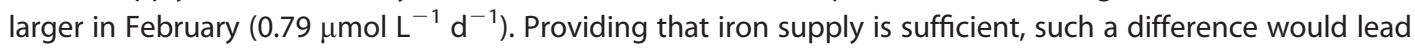
to phytoplankton variations more elevated at the seasonal time scale than at the ENSO time scale. During La Niña, deep thermocline and nutricline combine with weak westerly winds to lessen the upwelling impact.

These estimations rely on the assumption that upwelling mainly results from offshore Ekman transport induced by alongshore wind stress as proposed by Bakun [1973]. Other mechanisms may modify the coastal upwelling intensity. In eastern boundary systems, an onshore geostrophic flow may inhibit upwelling [McCreary et al., 1986; Huyer et al., 1987; Marchesiello and Estrade, 2010; Benazzouz et al., 2014; Messié and Chavez, 2015; Jacox et al., 2015]. Whether the magnitude of cross-shelf geostrophic flow generated by variations of the alongshore pressure gradient is sufficient to modify the offshore Ekman transport north of New Guinea at the seasonal or interannual time scale remains to be determined. Ekman pumping may also contribute to upwelling because of spatial variations of the wind stress and of the Coriolis parameter $f$. Ekman pumping $(\operatorname{curl}(\tau / f \rho))$ computed from the QuikSCAT wind stress (close to zero during El Niño and near $1 \mathrm{~m} \mathrm{~d}^{-1}$ in February) is weak compared to vertical velocities induced by the coastal divergence. However, the low reliability of scatterometer wind products near the coast does not allow determining properly the alongshore wind stress decay and wind stress curl. Therefore, improvements in remote sensing of the cross-shore structure of wind stress are needed for better estimations of both the Ekman transport and Ekman pumping.

We also note that the upwelling impact on chlorophyll remains local for most of WWEs and that phytoplankton-rich waters are restrained to the west by westward equatorial currents. For about $25 \%$ of WWEs, phytoplankton-rich waters extend eastward beyond New Ireland (Figure 6b), suggesting the influence of advection of nutrient-rich and phytoplankton-rich New Guinea waters toward the eastern part of the equatorial warm pool. The role of horizontal advection from the western warm pool has been emphasized during WWEs in several case studies of heat budget in which cold water is advected eastward by the wind-driven equatorial surface current. Sources of cold water result from local surface cooling [Ralph et al., 1997; Cronin and McPhaden, 1997] or are located in the Mindanao current region [Lengaigne et al., 2002] or north of New Guinea [Hasegawa et al., 2009]. In contrast, chlorophyll increases observed during WWEs in the equatorial warm pool have been ascribed to vertical processes [Siegel et al., 1995; Murakami et al., 2000] because the western Pacific ecosystem is considered as a uniform oligotrophic region where horizontal advection is supposed to be small. However, our results support a role for advection of nutrient-rich and chlorophyll-rich waters from the western warm pool. Such a role has been considered in previous studies based on satellite observations during the 2002-2003 El Niño or over the 1998-2010 time period [Messié, 2006; Radenac et al., 2013]. Regions north of New Guinea and near the Indonesian and Philippines coasts 
constitute pools of nutrient-rich and chlorophyll-rich waters likely to be advected eastward by the winddriven surface current during WWEs. Horizontal advection of mesotrophic waters may significantly contribute to the positive chlorophyll anomaly observed in the equatorial warm pool during El Niño because numerous WWEs prior and during events [Eisenman et al., 2005] should enhance the New Guinea coastal upwelling and eastward equatorial surface current. Such situations are more likely to occur when westerly winds blow in the western basin and not when they move toward the central basin as during the mature phase of the strong 1997-1998 event. Besides, the upwelling is associated with an offshore flow created by the convergence between the southeastward coastal current in the west and the northwestward flow exiting from Vitiaz Strait. Such a meridional transport of coastal waters contributes to cooling warm pool waters during WWEs as shown by Hasegawa et al. [2011] during the December 2001 WWE. It should affect heat budgets during austral summer and at the interannual time scale. Similarly, it must influence nutrient and phytoplankton exchanges between the coastal and open ocean ecosystems. The relative contributions of horizontal and vertical processes, exchanges between coastal and open ocean waters, and how they vary between El Niño events remain to be properly quantified.

\subsection{Penetration of Solomon Sea Waters}

In a recent study based on Voluntary Observing Ships data and outputs from a $1 / 12^{\circ}$ resolution OGCM, Delcroix et al. [2014] attributed the SST minimum and SSS maximum observed in austral winter along the Bismarck Sea coast to horizontal advection of cold and salty waters from the Solomon Sea. Variability in the penetration of waters from the Solomon Sea through Vitiaz Strait is therefore expected to lead to variations in SST and chlorophyll, depending on the variations of the thermal and chlorophyll gradient between the two basins.

In the Solomon Sea, interannual SST anomaly during El Niño is $-0.27^{\circ} \mathrm{C}$ while seasonal anomaly reaches $-1.26^{\circ} \mathrm{C}$ in August. West of Vitiaz Strait, surface waters are only about $0.2^{\circ} \mathrm{C}$ colder in August than during $\mathrm{El}$ Niño. No clear impact of Solomon Sea waters is observed on the austral winter surface chlorophyll in the Bismarck Sea. In contrast, Solomon Sea waters with chlorophyll content lower than in the Bismarck Sea are transported by the stronger NGCC during El Niño: a small negative chlorophyll anomaly $\left(\approx-0.02 \mathrm{mg} \mathrm{m}^{-3}\right)$ is observed west of the strait and the influence of the low chlorophyll Solomon Sea waters vanishes near $146^{\circ} \mathrm{E}$ (where local upwelling dominates). During La Niña, the impact of the cold coastal tongue decreases because the NGCC is weaker and the Solomon Sea warmer. Direct advection from one basin to the other is however not straightforward. Inflows of the NGCC and NGCUC through the narrow strait and topographic effects with small islands west of New Britain likely induce mesoscale processes that alter water mass properties. Measurements along repeated ship routes through the Solomon and Bismarck Seas show minimum SST at Vitiaz Strait [Delcroix et al., 2014] that may be due to waters upwelled south of New Britain and to mixing because of horizontal shear and perturbation of the vigorous flow by several offshore islands [Cresswell, 2000]. In addition, mesoscale activity near Vitiaz Strait at the surface and at depth has been demonstrated using drifters [Hristova and Kessler, 2012] and high-resolution simulations [Hristova et al., 2014; Djath et al., 2014]. But, mesoscale and submesoscale features (anticyclonic or cyclonic eddies filaments, fronts) have not been studied in this region, nor their seasonal and interannual variations and their potential influence on SST, nutrients, or biology.

\subsection{Other Processes}

Interannual anomalies of SST and chlorophyll $\left(-0.2^{\circ} \mathrm{C}\right.$ and $0.02 \mathrm{mg} \mathrm{m}^{-3}$ during El Niño and $0.2^{\circ} \mathrm{C}$ and $-0.01 \mathrm{mg} \mathrm{m}^{-3}$ during La Niña) are weaker than seasonal anomalies $\left(-0.4^{\circ} \mathrm{C}\right.$ and $0.05 \mathrm{mg} \mathrm{m}^{-3}$ in summer and $-0.2^{\circ} \mathrm{C}$ and $-0.04 \mathrm{mg} \mathrm{m}^{-3}$ in winter), and this is consistent with similarly differing influences of the coastal upwelling and of the penetration of Solomon Sea waters at the seasonal and interannual time scales. But other processes contributing to the warm pool SST and chlorophyll variations also affect temperature and chlorophyll variations north of New Guinea.

The SST variability is semiannual; a minimum is associated with coastal upwelling during the monsoon season and another one is related to transport of cold waters from the Solomon Sea by the strong NGCC during the trade wind season. But semiannual variation of the incident solar radiation (maxima in spring and fall) contributes to SST variations in the warm pool [Godfrey et al., 1998; Wang and McPhaden, 1999; Kim et al., 2012]. So, both upwelling and cold coastal tongue effects develop when the warm pool SST is minimum. 
The region near the eastern edge of the warm pool (EEWP) is characterized by "hot events" (SST around $30^{\circ} \mathrm{C}$ ) [Qin et al., 2007], high SLA, and chlorophyll below $0.07 \mathrm{mg} \mathrm{m}^{-3}$ [Radenac et al., 2013]. Warm and very oligotrophic waters of the EEWP shift zonally at the ENSO time scale. Their zonal displacements contribute to SST cooling (warming) and surface chlorophyll increase (decrease) in the western part of the warm pool during El Niño (La Niña) [Kim et al., 2012; Messié and Chavez, 2012]. During the 1999-2001 La Niña years, EEWP reaches its westernmost location, near New Guinea. During these years, the elevated regional SLA (deep thermocline) plays a role in decreasing the upwelling efficiency and in the weakening of the summer SST minimum.

Advection of waters from the far western Pacific may also influence the ocean north of New Guinea. Cold waters conveyed southward by the Mindanao current were then advected southeastward during the March 1997 WWE [Lengaigne et al., 2002]. In a similar way, phytoplankton-rich waters originating from the Indonesian or Philippines coast are likely to be advected eastward during WWEs [Radenac et al., 2013].

\subsection{Concluding Remarks}

Several cruises and moorings enabled describing and understanding aspects of the circulation north of New Guinea. The even scarcer biological and/or chemical observations give a partial biogeochemical view. Combining spaceborne data sets (wind, chlorophyll, SST, SLA, and surface currents) allowed putting in situ measurements in a larger scale context. This study characterizes wind, SST, chlorophyll, and circulation patterns at intraseasonal, seasonal, and interannual time scales. It also identifies the major processes involved in the local variability and their period and zone of activity.

At present, along-track altimetry is one of the few ways to resolve the meridional structure of the NGCC because of its fine horizontal resolution. Other products such as drifter-derived [Lumpkin and Johnson, 2013] or OSCAR [Bonjean and Lagerloef, 2002] surface current have a coarser resolution. However, missing along-track current anomaly, large inter-track distance (more than $300 \mathrm{~km}$ between neighboring tracks), and no reliable estimation of the mean alongshore absolute velocity prevent from fully resolving the alongshore circulation. The lack of detection of the current convergence near the Sepik River mouth during the northwest monsoon illustrates such shortcoming. Yet we believe that using such coastal dedicated processing of along-track altimeter data gives a realistic picture of the seasonal and interannual variations of the narrow western boundary surface current along the northern New Guinea coast. Several complementary measurement methods are needed to describe the full complex coastal circulation.

The ecosystem north of New Guinea experiences numerous influences and Higgins et al. [2006] pointed out how difficult it was to decipher the drivers of primary production and of phytoplankton composition. Ocean color is helpful to infer the variability of phytoplankton but process studies remain to be done to assess which factors (light, macronutrients, micronutrients, and $\mathrm{N}_{2}$ fixation) control primary productivity. Note that the interpretation of satellite chlorophyll images requires caution because of the complex water optical properties arising from the interplay of coastal particle-rich waters and oceanic waters. A better knowledge of the surface ecosystem will also help better understanding water optical properties and ocean color data in a region where turbidity is expected to be elevated because of the large sediment discharge by the Sepik and Mamberamo rivers.

This study proposes processes responsible for the SST and chlorophyll variability at the intraseasonal, seasonal, and interannual time scales. Quantifying the contribution of each process at different time scales requires using complementary in situ and satellite measurements and coupled physical-biogeochemical simulations. High-resolution circulation models have been run in the region [Hristova et al., 2014; Djath et al., 2014]. To our knowledge, coupling a biogeochemistry model remains to be done.

The economic development of the Pacific Island Countries and Territories is largely reliant on tuna fishery. The Bismarck Sea hosts a high density of skipjack tuna, the magnitude of which does not appear to vary seasonally but interannually [Lehodey et al., 2011a]. Influences of ecosystem and circulation north of New Guinea are far reaching and are thought to partially explain the higher skipjack biomass in the western equatorial warm pool following El Niño events [Lehodey, 2001; Lehodey et al., 2011b]. Finally, Gaspar et al. [2012] showed that variability of the surface NGCC is instrumental in the dispersal of hatchlings of the endangered western Pacific leatherback turtles, two nesting sites of which are located on the northern coast of New Guinea. Despite the socioeconomic issues, the circulation and ecosystem functioning of the 


\section{QAGU Journal of Geophysical Research: Oceans}

region are relatively poorly understood. A better understanding of the physical and biological processes north of New Guinea is a key point for managing regional resources.

\section{Acknowledgments}

Several freely available data contributed to this study. We thank the Ocean Biology Processing Group at the GSFC (http://oceancolor.gsfc.nasa. gov) for producing and distributing ocean color data, the US National Oceanographic Data Center and GHRSST (http://pathfinder.nodc.noaa. gov) for AVHRR Pathfinder Version 5.2 SST, RSS (http://www.ssmi.com) for TMI SST, CERSAT (http://cersat.ifremer.fr) for wind data, and OSCAR (http://www. oscar.noaa.gov) for near surface current. Along-track altimeter-derived sea level anomaly was produced and distributed by CTOH (http://ctoh.legos. obs-mip.fr/) and gridded altimetry SLA by AVISO (http://www.aviso.oceanobs. com/duacs). ADCP data were provided by the JASADCP (http://ilikai.soest. hawaii.edu/sadcp/) and the TOCS group of the JAMSTEC (http://www. godac.jamstec.go.jp). We also acknowledge use of the CARS 2009 (http://www.marine.csiro.au/ dunn/ cars2009) temperature and nitrate data. The Ferret program (http://ferret. pmel.noaa.gov/Ferret/) produced by NOAA's Pacific Marine Environmental Laboratory was used for graphics and some analyses. We are grateful to Thierry Delcroix and Séréna Illig for fruitful discussions at different stages of this study. We thank two anonymous reviewers for their careful reading and their useful suggestions. This work was supported by CNES and Fabien Léger benefited from CNES funding.

\section{References}

AVISO (1996), AVISO User Handbook: Merged Topex/Poseidon Products, AVI-NT-02-101-CN, Edition 3.0, 198 pp., CNES, Toulouse.

Bakun, A. (1973), Coastal upwelling indices, west coast of North America, 1946-71, NOAA Tech. Rep. NMFS SSRF-671, 103 pp., U.S. Dep. of Commer., Seattle, Wash.

Bell, J. D., T. J. H. Adams, J. E. Johnson, A. J. Hobday, and A. Sen Gupta (2011), Pacific communities, fisheries, aquaculture and climate change: An introduction, in Vulnerability of Tropical Pacific Fisheries and Aquaculture to Climate Change, edited by J. D. Bell et al., pp. $1-47$, Secr. of the Pac. Community, Noumea.

Benazzouz, A., S. Mordane, A. Orbi, M. Chagdali, K. Hilmi, A. Atillah, J. Lluís Pelegrí, and H. Demarcq (2014), An improved coastal upwelling index from sea surface temperature using satellite-based approach-The case of the Canary Current upwelling system, Cont. Shelf Res., 81, 38-54, doi:10.1016/j.csr.2014.03.012.

Bentamy, A., Y. Quilfen, and P. Flament (2002), Scatterometer wind fields: A new release over the decade 1991-2001, Can. J. Remote Sens., 28(3), 431-449.

Birol, F., M. Cancet, and C. Estournel (2010), Aspects of the seasonal variability of the Northern Current (NW Mediterranean Sea) observed by altimetry, J. Mar. Syst., 81(4), 297-311, doi:10.1016/j.jmarsys.2010.01.005.

Bonjean, F., and G. S. E. Lagerloef (2002), Diagnostic model and analysis of the surface currents in the tropical Pacific ocean, J. Phys. Oceanogr., 32(10), 2938-2954.

Boulanger, J.-P., C. Menkes, and M. Lengaigne (2004), Role of high- and low-frequency winds and wave reflection in the onset, growth and termination of the 1997-1998 El Nino, Clim. Dyn., 22, 267-280, doi:10.1007/s00382-003-0383-8.

Burns, K. A., G. Brunskill, D. Brinkman, and I. Zagorskis (2008), Organic carbon and nutrient fluxes to the coastal zone from the Sepik River outflow, Cont. Shelf Res., 28, 283-301.

Campbell, J. W., J. M. Blaisdell, and M. Darzi (1995), Level-3 SeaWiFS data products: Spatial and temporal binning algorithms, NASA Tech. Memo. TM-104566, vol. 32, 80 pp.

Casey, K. S., T. B. Brandon, P. Cornillon, and R. Evans (2010), The past, present and future of the AVHRR pathfinder SST program, in Oceanography From Space: Revisited, edited by V. Barale et al., pp. 273-287, Springer, Netherlands, doi:10.1007/978-90-481-8681-5_16.

Colin, C., J. R. Donguy, C. Henin, C. Oudot, and B. Wauthy (1973), Upper waters north of New Guinea in 1971, paper presented at the 3rd in Proceedings of the 3rd Cooperative Study of the Kuroshio and Adjacent Regions Symposium, Bangkok, Thailand, National Research Council of Thailand.

Cravatte, S., A. Ganachaud, Q.-P. Duong, W. S. Kessler, G. Eldin, and P. Dutrieux (2011), Observed circulation in the Solomon Sea from SADCP data, Prog. Oceanogr., 88, 116-130.

Cresswell, G. R. (2000), Coastal currents of northern Papua New Guinea, and the Sepik River outflow, Mar. Freshwater Res., 51, $553-564$.

Cronin, M. F., and M. J. McPhaden (1997), The upper ocean heat balance in the western equatorial Pacific warm pool during SeptemberDecember 1992, J. Geophys. Res., 102, 8533-8553.

Delcroix, T., J. Picaut, and G. Eldin (1991), Equatorial Kelvin and Rossby waves evidenced in the Pacific Ocean through GEOSAT sea level and surface current anomalies, J. Geophys. Res., 96, 3249-3262.

Delcroix, T., M.-H. Radenac, S. Cravatte, G. Alory, L. Gourdeau, F. Léger, A. Singh, and D. Varillon (2014), Sea surface temperature and salinity seasonal changes in the western Solomon and Bismarck Seas, J. Geophys. Res. Oceans, 119, 2642-2657, doi:10.1002/2013JC009733.

Djath, B., J. Verron, A. Melet, L. Gourdeau, B. Barnier, and J.-M. Molines (2014), Multiscale dynamical analysis of a high resolution numerical model simulation of the Solomon Sea circulation, J. Geophys. Res. Oceans, 119, 6286-6304, doi:10.1002/2013JC009695.

Durand, F., D. Shankar, F. Birol, and S. S. C. Shenoi (2008), Estimating boundary currents from satellite altimetry: A case study for the east coast of India, J. Oceanogr., 64(6), 831-845.

Dutrieux, P. (2009), Tropical western Pacific currents and the origin of intraseasonal variability below the thermocline, PhD thesis, Univ. of Hawai'i at Mānoa, Honolulu.

Eisenman, I., L. Yu, and E. Tziperman (2005), Westerly wind Burst: ENSO's tail rather than the dog?, J. Clim., 18(24), 5224-5238.

Eldin, G., A. Ganachaud, S. Cravatte, and C. Jeandel (2013), Pandora cruise provides an unprecedented description of the Solomon Sea, CLIVAR Exch., 61(18), 24-25.

Everitt, D. A., S. W. Wright, J. K. Volkman, D. P. Thomas, and E. J. Lindstrom (1990), Phytoplankton community compositions in the western equatorial Pacific determined from chlorophyll and carotenoid pigment distributions, Deep Sea Res., Part A, 37, 975-997.

Fieux, M. (2010), L'océan Planétaire, les Presses de l'ENSTA, Paris.

Gaspar, P., S. R. Benson, P. H. Dutton, A. Réveillère, G. Jacob, C. Meetoo, A. Dehecq, and S. Fossette (2012), Oceanic dispersal of juvenile leatherback turtles: Going beyond passive drift modeling, Mar. Ecol. Prog. Ser., 457, 265-284.

Godfrey, J. S., and E. J. Lindstrom (1989), The heat budget of the equatorial western Pacific surface mixed layer, J. Geophys. Res., 94, 8007-8017.

Godfrey, J. S., R. A. Houze Jr., R. H. Johnson, R. Lukas, J.-L. Redelsperger, A. Sumi, and R. Weller (1998), Coupled Ocean-Atmosphere Response Experiment (COARE): An interim report, J. Geophys. Res., 103, 14,395-14,450.

Gourdeau, L., J. Verron, A. Melet, W. Kessler, F. Marin, and B. Djath (2014), Exploring the mesoscale activity in the Solomon Sea: A complementary approach with a numerical model and altimetric data, J. Geophys. Res. Oceans, 119, 2290-2311, doi:10.1002/2013JC009614.

Harrison, D. E., and G. E. Vecchi (1997), Westerly wind events in the tropical Pacific, 1986-95, J. Clim., 10, 3131-3156.

Hasegawa, T., K. Ando, K. Mizuno, and R. Lukas (2009), Coastal upwelling along the north coast of Papua New Guinea and SST cooling over the pacific warm pool: A case study for the 2002/03 El Niño event, J. Oceanogr., 65, 917-833.

Hasegawa, T., K. Ando, K. Mizuno, R. Lukas, B. Taguchi, and H. Sasaki (2010), Coastal upwelling along the north coast of Papua New Guinea and El Niño events during 1981-2005, Ocean Dyn., 60, 1255-1269.

Hasegawa, T., K. Ando, and H. Sasaki (2011), Cold water flow and upper-ocean currents in the Bismarck Sea from December 2001 to January 2002, J. Phys. Oceanogr., 41(4), 827-834.

Higgins, H. W., D. J. Mackey, and L. Clementson (2006), Phytoplankton distribution in the Bismarck Sea north of Papua New Guinea: The effect of the Sepik River outflow, Deep Sea Res., Part I, 53(11), 1845-1863.

Hristova, H. G., and W. S. Kessler (2012), Surface circulation in the Solomon Sea derived from Lagrangian drifter observations, J. Phys. Oceanogr., 42, 448-458, doi:10.1175/JPO-D-11-099.1. 
Hristova, H. G., W. S. Kessler, J. C. McWilliams, and M. J. Molemaker (2014), Mesoscale variability and its seasonality in the Solomon and Coral Seas, J. Geophys. Res. Oceans, 119, 4669-4687, doi:10.1002/2013JC009741.

Huyer, A., R. L. Smith, and T. Paluszkiewicz (1987), Coastal upwelling off Peru during normal and El Niño times, 1981-1984, J. Geophys. Res., 92, 14,297-14,307, doi:10.1029/JC092iC13p14297.

Jacox, M. G., S. J. Bograd, E. L. Hazen, and J. Fiechter (2015), Sensitivity of the California Current nutrient supply to wind, heat, and remote ocean forcing, Geophys. Res. Lett., 42, 5950-5957, doi:10.1002/2015GL065147.

Joyce, T. M., R. Lukas, and E. Firing (1988) On the hydrostatic balance and equatorial geostrophy, Deep Sea Res., Part A, 35(8), $1255-1257$.

Kaneko, I., Y. Takatsuki, H. Kamiya, and S. Kawae (1998), Water property and current distributions along the WHP-P9 section (137 $\left.-142^{\circ} \mathrm{E}\right)$ in the western North Pacific, J. Geophys. Res., 103, 12,959-12,984.

Kim, S. T., J.-Y. Yu, and M.-M. Lu (2012), The distinct behaviors of Pacific and Indian Ocean warm pool properties on seasonal and interannual time scales, J. Geophys. Res., 117, D05128, doi:10.1029/2011JD016557.

Kineke, G. C., K. J. Woolfe, S. A. Kuehl, J. D. Milliman, T. M. Dellapenna, and R. G. Purdon (2000), Sediment export from the Sepik River, Papua New Guinea: Evidence for a divergent sediment plume, Cont. Shelf Res., 20(16), 2239-2266.

Kuroda, Y. (2000), Variability of currents off the northern coast of New Guinea, J. Oceanogr., 56, 103-116.

Lacan, F., and C. Jeandel (2001), Tracing Papua New Guinea imprint on the central Equatorial Pacific Ocean using neodymium isotopic compositions and Rare Earth Element patterns, Earth Planet. Sci. Lett., 186(3-4), 497-512.

Lagerloef, G. S. E., G. T. Mitchum, R. B. Lukas, and P. P. Niiler (1999), Tropical Pacific near-surface currents estimated from altimeter, wind, and drifter data, J. Geophys. Res., 104, 23,313-23,326.

Lehodey, P. (2001), The pelagic ecosystem of the tropical Pacific ocean: Dynamic spatial modelling and biological consequences of ENSO, Prog. Oceanogr., 49, 439-468.

Lehodey, P., I. Senina, B. Calmettes, J. Hampton, S. Nicol, P. Williams, J. Jurado Molina, M. Ogura, H. Kiyofuji, and S. Okamoto (2011a), SEAPODYM working progress and applications to Pacific skipjack tuna population and fisheries (Rev. 1), paper EB-WP 06 presented at Seventh Regular Session of Scientific Committee, Pohnpei, Federated States of Micronesia, 9-17 Aug.

Lehodey, P., et al. (2011b), Vulnerability of oceanic fisheries in the tropical Pacific to climate change, in Vulnerability of Tropical Pacific Fisheries and Aquaculture to Climate Change, edited by J. D. Bell et al., pp. 433-492, Secr. of the Pac. Community, Noumea.

Lengaigne, M., J.-P. Boulanger, C. Menkes, S. Masson, G. Madec, and P. Delecluse (2002), Ocean response to the March 1997 westerly wind event, J. Geophys. Res., 107(C12), 8015, doi:10.1029/2001JC000841.

Lengaigne, M., J.-P. Boulanger, C. Menkes, P. Delecluse, and J. Slingo (2004), Westerly wind events in the tropical Pacific and their influence on the coupled ocean-atmosphere system: A review, in Earth Climate: The Ocean-Atmosphere Interaction, Geophys. Monogr. Ser., vol. 147, pp. 49-69, AGU, Washington, D. C.

Lindstrom, E., R. Lukas, R. Fine, E. Firing, S. Godfrey, G. Meyers, and M. Tsuchiya (1987), The Western equatorial Pacific Ocean circulation study, Nature, 330, 533-537.

Lindstrom, E., J. Butt, R. Lukas, and S. Godfrey (1990), The flow through Vitiaz strait and St George's channel, Papua New Guinea, in The Physical Oceanography of Sea Straits, edited by J. Pratt, pp. 171-189, Kluwer Acad., Dordrecht, Netherlands.

Lukas, R. (1988), On the role of western Pacific air-sea interaction in the El Niño/Southern Oscillation Phenomenon, in Proceedings of the U.S. TOGA Western Pacific Air-Sea Interaction Workshop, U.S. TOGA Rep. USTOGA-8, edited by R. Lukas and P. Webster, pp. 43-69, Univ. Corp. for Atmos. Res., Boulder, Colo.

Lukas, R., and E. Firing (1984), The geostrophic balance of the Pacific Equatorial Undercurrent. Deep Sea Res., Part A, 31, 1, 61-66.

Lukas, R., and E. Lindstrom (1991), The mixed layer of the western equatorial Pacific Ocean, J. Geophys. Res., 96, 3343-3357.

Lukas, R., E. Firing, P. Hacker, P. L. Richardson, C. A. Collins, R. Fine, and R. Gammon (1991), Observations of the Mindanao current during the western equatorial Pacific Ocean circulation study, J. Geophys. Res., 96, 7089-7104.

Lumpkin, R., and G. C. Johnson (2013), Global ocean surface velocities from drifters: Mean, variance, El Nino-Southern Oscillation response, and seasonal cycle, J. Geophys. Res. Oceans, 118, 2992-3006, doi:10.1002/jgrc.20210.

Mackey, D. J., J. E. O'Sullivan, and R. J. Watson (2002), Iron in the western Pacific: A riverine or hydrothermal source for iron in the Equatorial Undercurrent?, Deep Sea Res., Part I, 49(5), 877-893.

Marchesiello, P., and P. Estrade (2010), Upwelling limitation by onshore geostrophic flow, J. Mar. Res., 68(1), 37-62.

Masuzawa, J. (1967), An oceanographic section from Japan to New Guinea at $137^{\circ}$ E in January 1967, Oceanogr. Mag., 19(2), 95-118.

Masuzawa, J. (1968), Second cruise for CSK, Ryofu Maru, January to March 1968, Oceanogr. Mag., 20(2), 173-185.

McClain, C. R., G. C. Feldman, and S. B. Hooker (2004), An overview of the SeaWiFS project and strategies for producing a climate research quality global ocean bio-optical time series, Deep Sea Res., Part II, 51(1-3), 5-42.

McCreary, J. P., S. R. Shetye, P. K. Kundu, and K. Pijush (1986), Thermohaline forcing of eastern boundary currents: With application to the circulation off the west coast of Australia, J. Mar. Res., 44(1), 71-92.

McPhaden, M. J., et al. (1998), The Tropical Ocean-Global Atmosphere observing system: A decade of progress, J. Geophys. Res., 103, $14,169-14,240$

Melet, A., L. Gourdeau, and J. Verron (2010), Variability in Solomon Sea circulation derived from altimeter sea level data, Ocean Dyn., 60(4), 883-900.

Messié, M. (2006), Contrôle de la dynamique de la biomasse phytoplanctonique dans le Pacifique tropical ouest, thèse de doctorat, Université Toulouse 3, Toulouse, France.

Messié, M., and F. P. Chavez (2012), A global analysis of ENSO synchrony: The oceans' biological response to physical forcing, J. Geophys. Res., 117, C09001, doi:10.1029/2012JC007938.

Messié, M., and F. P. Chavez (2015), Seasonal regulation of primary production in eastern boundary upwelling systems. Prog. Oceanogr., 134, 1-18, doi:10.1016/j.pocean.2014.10.011.

Messié, M., and M.-H. Radenac (2006), Seasonal variability of the surface chlorophyll in the western tropical Pacific from SeaWiFS data, Deep Sea Res., Part I, 53(10), 1581-1600.

Milliman, J. D., K. L. Farnsworth, and C. S. Albertin (1999), Flux and fate of fluvial sediments leaving large islands in the East Indies, J. Sea Res., 41, 97-107.

Muchtar, M. (2004), IndoTROPICS studies on the plume of the Mamberamo River into the Bismarck Sea, West Papua, Indonesia, Cont. Shelf Res., 24, 2521-2533.

Murakami, H., J. Ishizaka, and H. Kawamura (2000), ADEOS observations of chlorophyll a concentration, sea surface temperature, and wind stress change in the equatorial Pacific during the 1997 El Niño onset, J. Geophys. Res., 105, 19,551-19,559.

Murray, S., E. Lindstrom, J. Kindle, and E. Weeks (1995), Transport through the Vitiaz Strait, WOCE Notes, 7(1), 21-23.

Murtugudde, R. G., S. R. Signorini, J. R. Christian, A. J. Busalacchi, C. R. McClain, and J. Picaut (1999), Ocean color variability of the tropical Indo-Pacific basin observed by SeaWiFS during 1997-98, J. Geophys. Res., 104, 18,351-18,365. 
O'Carroll, A. G., R. W. Saunders, and J. G. Watts (2006), The measurement of the sea surface temperature by satellites from 1991 to 2005 , J. Atmos. Oceanic Technol., 23(11), 1573-1582.

Picaut, J., A. J. Busalacchi, M. J. McPhaden, and B. Camusat (1990), Validation of the geostrophic method for estimating zonal currents at the equator from GEOSAT altimeter data, J. Geophys. Res., 95, 3015-3024.

Puy, M., J. Vialard, M. Lengaigne, and E. Guilyardi (2015), Modulation of equatorial Pacific Westerly/Easterly Wind Events by the MaddenJulian Oscillation and convectively-coupled Rossby waves, Clim. Dyn., 10.1007/s00382-015-2695-x.

Qin, H., H. Kawamura, and Y. Kawai (2007), Detection of hot event in the equatorial Indo-Pacific warm pool using advanced satellite sea surface temperature, solar radiation, and wind speed, J. Geophys. Res., 112, C07015, doi:10.1029/2006JC003969.

Radenac, M.-H., and M. Rodier (1996), Nitrate and chlorophyll distributions in relation to thermohaline and current structures in the western tropical Pacific during 1985-1989, Deep Sea Res., Part II, 43, 725-752.

Radenac, M.-H., F. Léger, A. Singh, and T. Delcroix (2012), Sea surface chlorophyll signature in the tropical Pacific during eastern and central Pacific ENSO events, J. Geophys. Res., 117, C04007, doi:10.1029/2011JC007841.

Radenac, M.-H., M. Messié, F. Léger, and C. Bosc (2013), A very oligotrophic zone observed from space in the equatorial Pacific warm pool, Remote Sens. Environ., 134, 224-233, doi:10.1016/j.rse.2013.03.007.

Radic, A., F. Lacan, and J. W. Murray (2011), Iron isotopes in the seawater of the equatorial Pacific Ocean: New constraints for the oceanic iron cycle, Earth Planet. Sci. Lett., 306, 1-10, doi:10.1016/j.epsl.2011.03.015.

Ralph, E. A., K. N. Bi, P. P. Niiler, and Y. du Penhoat (1997), A Lagrangian description of the western equatorial Pacific response to the wind burst of December 1992: Heat advection in the warm pool, J. Clim., 10(7), 1706-1721.

Rébert, J.-P., J.-R. Donguy, G. Eldin, and K. Wyrtki (1985), Relations between sea-level, thermocline depth, heat content, and dynamic height in the tropical Pacific, J. Geophys. Res., 90, 11,719-11,725.

Reynolds, R. W., C. L. Gentemann, and G. K. Corlett (2010), Evaluation of AATSR and TMI satellite SST data, J. Clim., 23(1), 152-165.

Ridgway, K. R., J. R. Dunn, and J. L. Wilkin (2002), Ocean interpolation by four-dimensional weighted least squares-Application to the waters around Australasia, J. Atmos. Oceanic Technol., 19(9), 1357-1375.

Roblou, L., J. Lamouroux, J. Bouffard, F. Lyard, M. Le Henaff, A. Lombard, P. Marsaleix, P. De Mey, and F. Birol (2011), Post-processing altimeter data toward coastal applications and integration into coastal models, in Coastal Altimetry, edited by S. Vignudelli et al., pp. 217-246, Springer, Berlin.

Ropelewski, C. F., and M. S. Halpert (1996), Quantifying Southern Oscillation-precipitation relationships, J. Clim., 9, $1043-1059$.

Siegel, D. A., J. C. Ohlman, L. Washburn, R. R. Bidigare, C. T. Nosse, E. Fields, and Y. Zhou (1995), Solar radiation, phytoplankton pigments and the radiant heating of the equatorial Pacific warm pool, J. Geophys. Res., 100, 4885-4891.

Sciremammano, F. (1979), A suggestion for the presentation of correlations and their significance levels, J. Phys. Oceanogr., 9, $1273-1276$.

Slemons, L. O., J. W. Murray, J. Resing, B. Paul, and P. Dutrieux (2010), Western Pacific coastal sources of iron, manganese, and aluminum to the Equatorial Undercurrent, Global Biogeochem. Cycles, 24, GB3024, doi:10.1029/2009GB003693.

Smith, I., A. Moise, K. Inape, B. Murphy, R. Colman, S. Power, and C. Chung (2013), ENSO-related rainfall changes over the New Guinea region, J. Geophys. Res. Atmos., 118, 10,665-10,675, doi:10.1002/jgrd.50818.

Smith, I. N., A. F. Moise, and R. A. Colman (2012), Large-scale circulation features in the tropical western Pacific and their representation in climate models, J. Geophys. Res., 117, D04109, doi:10.1029/2011JD016667.

Torrence, C., and G. P. Compo (1998), A practical guide to wavelet analysis, Bull. Am. Meteorol. Soc., 79, 61-78.

Tsuchiya, M., R. Lukas, R. A. Fine, E. Firing, and E. Lindstrom (1989), Source waters of the Pacific equatorial undercurrent, Prog. Oceanogr., 23, 101-147.

Turk, D., M. J. McPhaden, A. J. Busalacchi, and M. R. Lewis (2001), Remotely sensed biological production in the equatorial Pacific, Science, 293(20), 471-474.

Ueki, I., Y. Kashino, and Y. Kuroda (2003), Observation of current variations off the New Guinea coast including the 1997-1998 El Niño period and their relationship with Sverdrup transport, J. Geophys. Res., 108(C7), 3243, doi:10.1029/2002JC001611.

Wang, W., and M. J. McPhaden (1999), The surface layer heat balance in the equatorial Pacific Ocean, Part I: Mean seasonal cycle, J. Phys. Oceanogr., 29(8), 1812-1831.

Webster, P. J., and R. Lukas (1992), TOGA-COARE: The coupled ocean-atmosphere response experiment, Bull. Am. Meteorol. Soc., 73, 13771416.

Wyrtki, K. (1957), Die Zirkulation an der Oberfläche der Südostasiatischen Gewässer, Dtsch. Hydrogr. Z., 10(1), 1-13.

Wyrtki, K. (1961), Physical oceanography of the Southeast Asian waters, NAGA Rep. 2, 195 pp., Scripps Inst. of Oceanogr., La Jolla, Calif.

Yoder, J. A., and M. Kennelly (2003), Seasonal and ENSO variability in global ocean phytoplankton chlorophyll derived from 4 years of SeaWiFS measurements, Global Biogeochem. Cycles, 17(4), 1112, doi:10.1029/2002GB001942. 